\title{
Elemental composition and oxidation of chamber organic aerosol
}

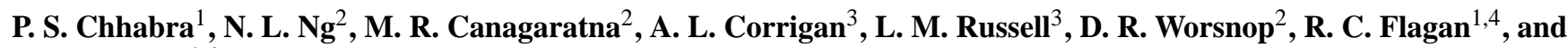 \\ J. H. Seinfeld ${ }^{1,4}$ \\ ${ }^{1}$ Division of Chemistry and Chemical Engineering, California Institute of Technology, Pasadena, CA, USA \\ ${ }^{2}$ Aerodyne Research, Inc. Billerica, MA, USA \\ ${ }^{3}$ Scripps Institution of Oceanography, University of California, San Diego, CA, USA \\ ${ }^{4}$ Division of Engineering and Applied Science, California Institute of Technology, Pasadena, CA, USA
}

Received: 21 March 2011 - Published in Atmos. Chem. Phys. Discuss.: 30 March 2011

Revised: 15 August 2011 - Accepted: 24 August 2011 - Published: 1 September 2011

\begin{abstract}
Recently, graphical representations of aerosol mass spectrometer (AMS) spectra and elemental composition have been developed to explain the oxidative and aging processes of secondary organic aerosol (SOA). It has been shown previously that oxygenated organic aerosol (OOA) components from ambient and laboratory data fall within a triangular region in the $\mathrm{f}_{44}$ vs. $\mathrm{f}_{43}$ space, where $\mathrm{f}_{44}$ and $\mathrm{f}_{43}$ are the ratios of the organic signal at $\mathrm{m} / \mathrm{z} 44$ and 43 to the total organic signal in AMS spectra, respectively; we refer to this graphical representation as the "triangle plot." Alternatively, the Van Krevelen diagram has been used to describe the evolution of functional groups in SOA. In this study we investigate the variability of SOA formed in chamber experiments from twelve different precursors in both "triangle plot" and Van Krevelen domains. Spectral and elemental data from the high-resolution Aerodyne aerosol mass spectrometer are compared to offline species identification analysis and FTIR filter analysis to better understand the changes in functional and elemental composition inherent in SOA formation and aging. We find that SOA formed under high- and low- $\mathrm{NO}_{\mathrm{x}}$ conditions occupy similar areas in the "triangle plot" and Van Krevelen diagram and that SOA generated from already oxidized precursors allows for the exploration of areas higher on the "triangle plot" not easily accessible with non-oxidized precursors. As SOA ages, it migrates toward the top of the triangle along a path largely dependent on the precursor identity, which suggests increasing organic acid content and decreasing mass spectral variability. The most oxidized SOA come from the photooxidation of methoxyphenol precursors which yielded SOA O/C ratios near unity. $\alpha$-pinene ozonolysis and naphthalene photooxidation SOA systems have had the highest degree of mass closure in previous chemical char-
\end{abstract}



Correspondence to: J. H. Seinfeld (seinfeld@caltech.edu) acterization studies and also show the best agreement between AMS elemental composition measurements and elemental composition of identified species within the uncertainty of the AMS elemental analysis. In general, compared to their respective unsaturated SOA precursors, the elemental composition of chamber SOA follows a slope shallower than -1 on the Van Krevelen diagram, which is indicative of oxidation of the precursor without substantial losss of hydrogen, likely due to the unsaturated nature of the precursors. From the spectra of SOA studied here, we are able to reproduce the triangular region originally constructed with ambient OOA compents with chamber aerosol showing that SOA becomes more chemically similar as it ages. Ambient data in the middle of the triangle represent the ensemble average of many different SOA precursors, ages, and oxidative processes.

\section{Introduction}

Organic compounds comprise a significant fraction of ambient submicron aerosol mass (Zhang et al., 2007; Jimenez et al., 2009) with numerous sources and atmospheric processes contributing to their chemical complexity (Hallquist et al., 2009). Secondary organic aerosol (SOA) forms from the gas-phase oxidation of a number of anthropogenic and biogenic volatile organic compounds (VOCs) (Kroll and Seinfeld, 2008; Robinson et al., 2007; Lim et al., 2010; Donahue et al., 2009; Goldstein and Galbally, 2007; De Gouw and Jimenez, 2009). Although typically only a portion of the multitude of compounds present in SOA can be identified on a molecular level, on-line instruments like the Aerodyne Aerosol Mass Spectrometer (AMS) (Jayne et al., 2000; Canagaratna et al., 2007) can provide bulk, chemical characterization in real-time.

Published by Copernicus Publications on behalf of the European Geosciences Union. 
Recently, two important methods using AMS data to characterize the chemical nature of OA have been proposed. Heald et al. (2010) applied the Van Krevelen diagram to the bulk elemental composition of ambient and laboratory OA formed under a wide range of reaction conditions. Previous investigations have used the Van Krevelen diagram to map individual masses identified by high resolution electrospray ionization mass spectrometry (ESI-MS), but not for OA as a whole (Reinhardt et al., 2007; Walser et al., 2008; Bateman et al., 2009). Originally developed to describe the elemental composition of coal, the Van Krevelen diagram has axes of hydrogen to carbon $(\mathrm{H} / \mathrm{C})$ molar ratios and oxygen to carbon $(\mathrm{O} / \mathrm{C})$ molar ratios. Changes in functionality of $\mathrm{OA}$ are traced in this space along a line of a particular slope. For instance, when an aliphatic functionality is replaced by a carbonyl functionality, the resulting line on a Van Krevelen has a slope of -2 . Substituting aliphatic to alcohol or peroxide functionality produces a line with a slope of zero. Addition of carboxylic acids or hydroxycarbonyls gives a -1 slope. Hydration or condensation reactions follow a line with a slope of +2 . Heald et al. (2010) found that bulk OA elemental ratios from both laboratory and ambient atmospheres occupy a tight range on the Van Krevelen diagram with a slope of -1 , implying that OA aging involves, on average, the addition of carboxylic acids or equal amounts of alcohol and carbonyl functionalities.

$\mathrm{Ng}$ et al. (2010) used positive matrix factorization techniques (Zhang et al., 2005; Lanz et al., 2007; Ulbrich et al., 2009) and compiled the factor analysis for 43 Northern Hemisphere AMS datasets of OA. They found that at most sites AMS spectra can be separated into oxygenated OA (OOA) and hydrocarbon-like OA (HOA) components (Zhang et al., 2007). For many datasets, OOA was further subcategorized into low-volatility OOA (LV-OOA) and semi-volatile OOA (SV-OOA) (Jimenez et al., 2009). LV-OOA has been described as aged OOA, with spectra dominated by mass fragment $\mathrm{CO}_{2}{ }^{+}$at $m / z 44$, and SV-OOA, described as "fresh" OOA with an intense signal at $\mathrm{C}_{2} \mathrm{H}_{3} \mathrm{O}^{+}$at $m / z, 43$ as well. Mass fragment $\mathrm{CO}_{2}{ }^{+}$has been considered a marker ion for organic acids in OA, as it is known to form from the thermal decarboxylation of many different oxo-, di-, and polycarboxylic acids (Alfarra, 2004; Aiken et al., 2007; Takegawa et al., 2007; Duplissy et al., 2011). Fragment ion $\mathrm{C}_{2} \mathrm{H}_{3} \mathrm{O}^{+}$, conversely, has been hypothesized to form from non-acid oxygen-containing organic compounds. Since $\mathrm{m} / \mathrm{z} 43$ and 44 are the dominant ions in SV- and LV-OOA spectra and represent different functionalities, Ng et al. (2010) plotted $f_{44}$ vs. $f_{43}$ for all OOA spectra from different sites, where $f_{44}$ and $\mathrm{f}_{43}$ are the ratios of $\mathrm{m} / \mathrm{z} 44$ and $\mathrm{m} / \mathrm{z}, 43$ to the total OA signal in the spectrum, respectively. $\mathrm{Ng}$ et al. (2010) found that the OOA components clustered into a triangular region with wide variability across $\mathrm{f}_{43}$ at low values of $\mathrm{f}_{44}$ that narrows as $\mathrm{f}_{44}$ increases. As a consequence, LV-OOA data tend to group in the top half of the "triangle plot" and SV-OOA in the lower half. $\mathrm{Ng}$ et al. (2010) concluded that OOA components be- come more similar in terms of oxidation state with increasing photochemical age, regardless of source. The most oxidized spectra tend to resemble that of fulvic acid.

Chamber experiments have long been the gold standard to determine SOA formation mechanisms and to constrain the chemistry and yields of SOA. Chamber studies, however, cannot typically reach the oxidant exposures achieved in the ambient atmosphere (Rudich et al., 2007; Kroll and Seinfeld, 2008; Hallquist et al., 2009). Most recently in the context of AMS spectral factors, the studies of both Chhabra et al. (2010) and Ng et al. (2010) found that SOA from chamber studies typically does not reach the degree of oxygenation of ambient LV-OOA. For example, Heald et al. (2010) presented data from Shilling et al. (2009), in which the most oxidized SOA from $\alpha$-pinene ozonolysis has an $\mathrm{O} / \mathrm{C}$ of approximately 0.4 , whereas SOA from the MILAGRO (Mexico City) campaign (Aiken et al., 2009) surpasses 0.6. Ng et al. (2010) noted that most laboratory chamber data fall into the lower half of the "triangle plot", showing that laboratory OA is closer to SV-OOA than LV-OOA. Like SV-OOA, chamber SOA has high variability in $\mathrm{f}_{43}$, likely a result of the variety of precursors, oxidants, and other experimental variables. In chamber investigations in which SOA is generated at total organic loadings higher than those of ambient OA, more volatile, less oxygenated species partition into the particle phase than would at lower aerosol loadings. Additionally, chamber experiments are typically carried out for less than $\sim 24 \mathrm{~h}$, shorter than the atmospheric lifetime ( $\sim 1$ week) of ambient aerosol, and therefore not accessing further oxidation that might be occurring over this extended time scale. A comprehensive study by Chhabra et al. (2010) compared the elemental composition of five different chamber systems and found that monoaromatic- and naphthalene-derived SOA can reach $\mathrm{O} / \mathrm{C}$ ratios upward of 0.7 , approaching those of ambient measurements, and thus emphasizing the importance of $\mathrm{OH}$ exposure and precursor identity on SOA oxidation state.

In this study, we build on the previous investigation of Chhabra et al. (2010) by exploring the variability of chamber SOA in both Van Krevelen and "triangle plot" spaces. In addition to the systems studied in Chhabra et al. (2010) (glyoxal uptake, $\alpha$-pinene ozonolysis, isoprene photooxidation, monoaromatic photooxidation, and naphthalene photooxidation), we present high-resolution time-of-flight AMS (HR-ToF-AMS) spectra and elemental composition of chamber SOA from $\alpha$-pinene photooxidation, methoxyphenol photooxidation, and unsaturated aldehyde photooxidation. Structures for each of the twelve precursors are shown in Figure 1. We compare the elemental composition as measured by the AMS to molecular species identified by off-line methods for each SOA system as well as FTIR measurements of $\alpha$-pinene photooxidation and guaiacol photooxidation SOA. The goal of this work is to assess the extent to which SOA molecular and functional group composition analyses support the overall analysis of SOA formation and aging as represented in the Van Krevelen and "triangle plot" spaces. 


\section{Experimental section}

\subsection{Chamber operation}

Chamber operation and experimental methods for glyoxal uptake, $\alpha$-pinene ozonolysis, monoaromatic, isoprene, and naphthalene photooxidation experiments are described in Chhabra et al. (2010). Experimental methods for $\alpha$-pinene, methoxyphenol, and aldehyde photooxidation were nearly identical and are described in detail in Chan et al. (2010). In experiments in which methyl nitrite $\left(\mathrm{CH}_{3} \mathrm{ONO}\right)$ was used as the $\mathrm{OH}$ precursor, $\mathrm{CH}_{3} \mathrm{ONO}$ was vaporized into an evacuated $500 \mathrm{~mL}$ glass bulb and introduced into the chamber with an air stream of $5 \mathrm{~L} \mathrm{~min}^{-1}$. The mixing ratio of $\mathrm{CH}_{3} \mathrm{ONO}$ injected was estimated to be $200-400 \mathrm{ppb}$, based on the vapor pressure in the glass bulb measured using a capacitance manometer (MKS). Experimental conditions for each system are summarized in Table 1. All experiments were performed in the Caltech dual $28 \mathrm{~m}^{3}$ Teflon laboratory chambers (Cocker et al., 2001; Keywood et al., 2004) over the period 2007-2010. Each chamber has a dedicated Differential Mobility Analyzer (DMA, TSI model 3081) coupled with a condensation nucleus counter (TSI model 3760) for measuring aerosol size distribution and number and volume concentration. Temperature, relative humidity $(\mathrm{RH})$, ozone $\left(\mathrm{O}_{3}\right)$, $\mathrm{NO}$, and $\mathrm{NO}_{\mathrm{x}}$ were continuously monitored. For seeded experiments, ammonium sulfate seed particles were generated by atomization of a dilute aqueous ammonium sulfate solution using a constant rate atomizer.

\subsection{High-Resolution Time-of-Flight Aerosol Mass Spectrometer}

HR-ToF-AMS (Canagaratna et al., 2007; DeCarlo et al., 2006) spectra were analyzed as described in Chhabra et al. (2010). Briefly, in the mode of operation, the AMS was switched once every minute between the high-resolution "Wmode" and the lower resolution, higher sensitivity "V-mode". The "V-mode" data were analyzed using a fragmentation table to separate sulfate, ammonium, and organic spectra and to time-trace specific mass-to-charge ratios (Allan et al., 2004). "W-mode" data were analyzed using a separate highresolution spectra toolbox known as PIKA to determine the chemical formulas contributing to distinct mass-to-charge $(\mathrm{m} / \mathrm{z})$ ratios (DeCarlo et al., 2006). "V-mode" data were used in "triangle plots" and "W-mode" data were used in Van Krevelen diagrams.

Default values were used for the $\mathrm{CO}_{2}{ }^{+}$signal originating from chamber air as FTIR measurements showed the concentration of $\mathrm{CO}_{2}$ in the chamber air is nominally the same as that in the atmosphere. Ratios of the particle-phase signals of $\mathrm{CO}^{+}$to $\mathrm{CO}_{2}{ }^{+}$were determined to be close to 1 (Supplement) for most experiments so this value was used for all experiments except those of glyoxal uptake for which a value of 5 was used. The signals from $\mathrm{H}_{2} \mathrm{O}^{+}, \mathrm{OH}^{+}$, and $\mathrm{O}^{+}$in the

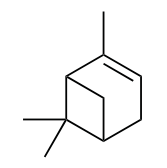

a-pinene<smiles>c1ccc2ccccc2c1</smiles>

naphthalene<smiles>C=CC=O</smiles>

acrolein<smiles>C=CC(=C)C</smiles>

isoprene<smiles>Oc1ccccc1</smiles>

phenol<smiles>C=C(C)C=O</smiles>

methacrolein<smiles>Cc1ccccc1</smiles>

toluene<smiles>COc1ccccc1O</smiles>

guaiacol<smiles>C/C=C/C=O</smiles>

crotonaldehyde<smiles>Cc1cccc(C)c1</smiles>

$m$-xylene<smiles>COc1cccc(OC)c1O</smiles>

syringol<smiles>O=CC=O</smiles>

Fig. 1. Structures of the SOA precursors presented in this study.

particulate organic mass may suffer interference from gasphase $\mathrm{H}_{2} \mathrm{O}$, and their organic contributions were estimated as suggested in Aiken et al. (2008). Particulate nitrogen signals were observed in high- $\mathrm{NO}_{\mathrm{x}}$ photooxidation experiments, originating mostly from $\mathrm{NO}^{+}$and $\mathrm{NO}_{2}{ }^{+}$ions. $\mathrm{Al}-$ though gas-phase nitric acid is produced from the $\mathrm{OH}+\mathrm{NO}_{2}$ reaction, at low chamber humidities nitric acid is not expected to partition appreciably into the particle phase. Thus, the signals of $\mathrm{NO}^{+}$and $\mathrm{NO}_{2}{ }^{+}$ions were included as part of the organic mass in high- $\mathrm{NO}_{\mathrm{x}}$ photooxidation experiments.

\subsection{Fourier Transform Infrared Spectroscopy (FTIR)}

Samples for FTIR analysis were collected on Teflon filters (Pall Inc., Ann Arbor, MI, $37 \mathrm{~mm}$ diameter, $1.0 \mu \mathrm{m}$ pore size, teflo membrane), following the collection, storage, analysis, and peak-fitting techniques described by Russell et al. (2009). Specifically, a Bruker Tensor 27 FTIR Spectrometer with a DTGS detector (Bruker, Waltham, MA) was used to scan filters before and after sample collection; samples were frozen during transport and storage to reduce evaporative loss of organics and reaction. An automated algorithm was used for subtracting Teflon (using the pre-scanned spectra) and ammonium, baselining, peak-fitting, and error estimation (Russell et al., 2009). Mass concentrations of alkane, carboxylic acid, hydroxyl, amine, non-acid carbonyl, organonitrate, alkene, and aromatic functional groups were quantified using previously reported algorithms and standards (Russell et al., 2009; Day et al., 2010).

FTIR O/C and $\mathrm{H} / \mathrm{C}$ ratios were determined from measured organic bond absorbances by calculating the estimated moles of oxygen, carbon, and hydrogen associated with each measured bond and its associated functional group, as described in the Supplement (Russell et al., 2009; Russell, 2003). Since 
Table 1. Experimental conditions and results.

\begin{tabular}{|c|c|c|c|c|c|c|c|c|}
\hline Expt.\# & VOC System & Oxidant Precursor & $\begin{array}{l}\mathrm{RH} \\
(\%)\end{array}$ & $\begin{array}{r}{[\mathrm{NO}]_{0}} \\
(\mathrm{ppb})\end{array}$ & $\begin{array}{r}{\left[\mathrm{NO}_{2}\right]_{0}} \\
(\mathrm{ppb})\end{array}$ & $\begin{array}{r}\text { VOC Reacted } \\
(\mathrm{ppb})\end{array}$ & $\begin{array}{r}\text { Seed Vol. } \\
\left(\mu \mathrm{m}^{3} \mathrm{~cm}^{-3}\right)\end{array}$ & $\begin{array}{r}\Delta \mathrm{M}_{0}(\mathrm{Max})^{\mathrm{d}} \\
\quad\left(\mu \mathrm{g} \mathrm{m}^{-3}\right)\end{array}$ \\
\hline 1 & glyoxal uptake & - & 60 & $<\operatorname{det}^{\mathrm{a}}$ & $<\operatorname{det}^{\mathrm{a}}$ & $182^{\mathrm{b}}$ & 87 & 68.3 \\
\hline 2 & $\alpha$-pinene & $\mathrm{O}_{3}$ & 5.4 & $<\operatorname{det}^{\mathrm{a}}$ & $<\operatorname{det}^{\mathrm{a}}$ & $50^{\mathrm{c}}$ & 12.5 & 62.0 \\
\hline 3 & $\alpha$-pinene $+\mathrm{OH}$ & $\mathrm{H}_{2} \mathrm{O}_{2}$ & 4.2 & $<\operatorname{det}^{\mathrm{a}}$ & $<\operatorname{det}^{\mathrm{a}}$ & 46 & 13.7 & 63.9 \\
\hline 4 & $\alpha$-pinene $+\mathrm{OH}$ & $\mathrm{CH}_{3} \mathrm{ONO}$ & 4.9 & 447 & 400 & 47 & 15.4 & 53.7 \\
\hline 5 & isoprene $+\mathrm{OH}$ & $\mathrm{H} 2 \mathrm{O} 2$ & 5.2 & $<\operatorname{det}^{\mathrm{a}}$ & $<\operatorname{det}^{\mathrm{a}}$ & 49 & 16.2 & 8.2 \\
\hline 6 & isoprene $+\mathrm{OH}$ & HONO & $<10$ & 536 & 400 & 267 & 11.7 & 10.0 \\
\hline 7 & toluene $+\mathrm{OH}$ & $\mathrm{H}_{2} \mathrm{O}_{2}$ & $<10$ & $<\operatorname{det}^{\mathrm{a}}$ & $<\operatorname{det}^{\mathrm{a}}$ & 112 & 10.9 & 151.3 \\
\hline 8 & toluene $+\mathrm{OH}$ & HONO & $<10$ & 583 & 423 & 136 & 9.3 & 54.3 \\
\hline 9 & $m$-xylene $+\mathrm{OH}$ & $\mathrm{H}_{2} \mathrm{O}_{2}$ & $<10$ & $<\operatorname{det}^{\mathrm{a}}$ & $<\operatorname{det}^{\mathrm{a}}$ & 114 & 9.8 & 200.9 \\
\hline 10 & $m$-xylene $+\mathrm{OH}$ & HONO & $<10$ & 501 & 538 & 200 & 9.3 & 55.2 \\
\hline 11 & naphthalene $+\mathrm{OH}$ & $\mathrm{H}_{2} \mathrm{O}_{2}$ & 8.3 & $<\operatorname{det}^{\mathrm{a}}$ & $<\operatorname{det}^{\mathrm{a}}$ & $20^{\mathrm{c}}$ & 10.5 & 70.9 \\
\hline 12 & naphthalene $+\mathrm{OH}$ & HONO & 6.3 & 431 & 370 & $25^{\mathrm{c}}$ & 12.8 & 43.8 \\
\hline 13 & phenol $+\mathrm{OH}$ & $\mathrm{H}_{2} \mathrm{O}_{2}$, nucleation & 4.9 & $<\operatorname{det}^{\mathrm{a}}$ & $<\operatorname{det}^{\mathrm{a}}$ & 21 & 0.1 & 30.5 \\
\hline 14 & phenol $+\mathrm{OH}$ & HONO, nucleation & 3.7 & 332 & 545 & 19 & 0.0 & 24.8 \\
\hline 15 & guaiacol $+\mathrm{OH}$ & $\mathrm{H}_{2} \mathrm{O}_{2}$ & 5.7 & $<\operatorname{det}^{\mathrm{a}}$ & $<\operatorname{det}^{\mathrm{a}}$ & 6 & 16.3 & 11.9 \\
\hline 16 & guaiacol $+\mathrm{OH}$ & HONO & 4.8 & 267 & 427 & 7 & 12.6 & 12.8 \\
\hline 17 & syringol $+\mathrm{OH}$ & $\mathrm{H}_{2} \mathrm{O}_{2}$ & 3.7 & $<\operatorname{det}^{\mathrm{a}}$ & $<\operatorname{det}^{\mathrm{a}}$ & 108 & 10.8 & 228 \\
\hline 18 & syringol $+\mathrm{OH}$ & HONO, nucleation & 3.7 & $<\operatorname{det}^{\mathrm{a}}$ & $<\operatorname{det}^{\mathrm{a}}$ & 50 & 0.0 & 34.8 \\
\hline 19 & acrolein $+\mathrm{OH}$ & HONO & 7.2 & 215 & 389 & 412 & 13.2 & 21.3 \\
\hline 20 & methacrolein $+\mathrm{OH}$ & HONO & 9.3 & 725 & 368 & 186 & 11.4 & 10.1 \\
\hline 21 & crotonaldehyde $+\mathrm{OH}$ & HONO & 9.0 & 215 & 370 & 252 & 12.1 & 14.0 \\
\hline
\end{tabular}

a Below the detection limit of the measurement.

b Equilibrium concentration.

$\mathrm{c}$ approximate initial concentration.

d Mass loadings are calculated by multiplying the change in DMA volume by an estimated density. Estimated densities of glyoxal, $\alpha$-pinene, isoprene (and unsaturated aldehydes), monoaromatics, and naphthalene SOA were taken from Galloway et al. (2009); Bahreini et al. (2005); Kroll et al. (2006); Ng et al. (2007); Chan et al. (2009) respectively.

alkene groups were below detection, an upper bound was considered to be their detection limit and a lower bound was considered zero. The degree of saturation for other functional groups was weighted by the saturation in the reactants $(\alpha$-pinene and guaiacol). Hydrogen associated with amine groups was omitted since it is assumed that any ammonium is part of the inorganic seed rather than SOA.

\section{Results}

Elemental composition and high resolution-spectra of SOA derived from $\alpha$-pinene ozonolysis, glyoxal uptake into seed aerosol, and monoaromatic, isoprene, and naphthalene photooxidation have been described in detail in Chhabra et al. (2010). Tabulated elemental ratios and high-resolution spectra for $\alpha$-pinene, methoxyphenol, and unsaturated aldehyde photooxidation SOA are provided in the Supplementary Material. High-resolution spectra for SOA formed under similar conditions for each parent organic were identical; thus, one experiment for each system is presented. Raw measurement of elemental ratios requires calibration factors derived from the elemental analysis of laboratory standards. The calibration factors determined by Aiken et al. (2008) of 0.91 for H/C and 0.75 for $\mathrm{O} / \mathrm{C}$ were used. The uncertainty estimates of the calibration factors reported for $\mathrm{O} / \mathrm{C}$ and $\mathrm{H} / \mathrm{C}$ are $31 \%$ and $10 \%$ respectively. Uncertainty in AMS elemental analysis and offline speciation is discussed in detail in Chhabra et al. (2010).

\section{1 $\alpha$-pinene SOA}

Figure 2 illustrates the "triangle plot" (Panel a) and Van Krevelen diagram (Panels $b$ and $\mathrm{c}$ ) for SOA derived from $\alpha$-pinene ozonolysis and photooxidation. The time progression of each system is illustrated in Panel a with open and closed circles representing the beginning and end of each experiment, respectively. Consistent with previous studies (Chhabra et al., 2010; Shilling et al., 2009), as the SOA mass formed by $\alpha$-pinene ozonolysis increases, the $\mathrm{O} / \mathrm{C}$ ratio and $\mathrm{f}_{44}$ decrease, behavior that is a result of increased partitioning of less oxidized semivolatile compounds into a growing OA medium. Oxygen-to-carbon ratios for $\alpha$-pinene photooxidation SOA are approximately the same as those of ozonolysis SOA, however $\mathrm{H} / \mathrm{C}$ ratios are slightly higher at 1.6. Similar to $\alpha$-pinene ozonolysis SOA, the $\mathrm{O} / \mathrm{C}$ ratios of photooxidation $\mathrm{SOA}$ under both $\mathrm{NO}_{\mathrm{x}}$ conditions decrease as OA mass increases, behavior manifested in the Van Krevelen 

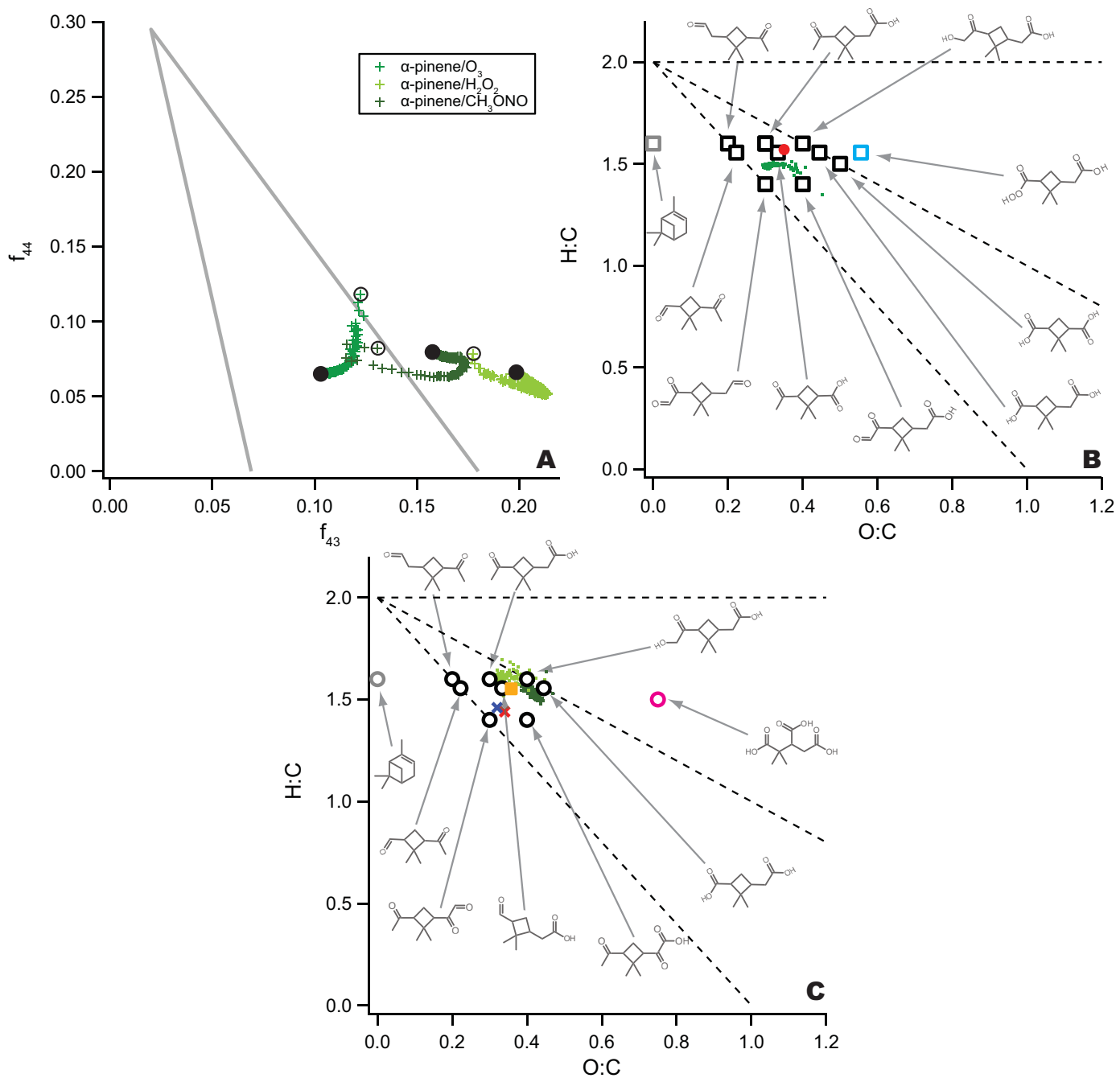

Fig. 2. (A) "Triangle plot" for $\alpha$-pinene SOA formed from ozonolysis and high- and low- $\mathrm{NO}_{\mathrm{x}}$ photooxidation. Here and in subsequent figures, the outline of the triangle ( $\mathrm{Ng}$ et al., 2010) is shown in gray. Open and closed black circles represent the beginning and end of the experiments, respectively. (B) Van Krevelen diagram for SOA formed from $\alpha$-pinene ozonolysis. $\alpha$-pinene and SOA products identified by Yu et al. (1999) represented by gray and black boxes respectively. The molar weighted average of the elemental ratios of identified SOA products is represented by the red circle (Chhabra et al., 2010). The blue square denotes peroxypinic acid, a product of $\alpha$-pinene ozonolysis proposed by Docherty et al. (2005). Here and in subsequent figures, lines with slopes of $0,-1$ and -2 are represented by dashed lines. (C) Van Krevlen diagram for SOA formed from the high- and low- $\mathrm{NO}_{\mathrm{x}}$ photooxidation of $\alpha$-pinene. $\alpha$-pinene and SOA products identified by Jaoui and Kamens (2001) and Szmigielski et al. (2007) are represented by black and pink circles, respectively. The mass weighted average $\mathrm{O} / \mathrm{C}$ and $\mathrm{H} / \mathrm{C}$ calculated from Jaoui and Kamens (2001) is represnted by an orange square. Elemental ratios as measured by FTIR data are represented by red $\left(\right.$ low- $\left.-\mathrm{NO}_{\mathrm{X}}\right)$ and blue $\left(\right.$ high- $\left.\mathrm{NO}_{\mathrm{X}}\right)$ crosses.

diagram but more readily apparent in the "triangle plot" with decreases in $\mathrm{f}_{44}$ and increases in $\mathrm{f}_{43}$. In contrast to ozonolysis SOA, however, photooxidation processes eventually overtake semivolatile partitioning and the oxidation state of photooxidation SOA increases, represented by increases in $\mathrm{f}_{44}(\mathrm{Ng}$ et al., 2010). Towards the end of $\alpha$-pinene photooxidation experiments, data in Panel a tend to migrate toward the top of the "triangle plot".
The elemental composition of identified compounds in $\alpha$ pinene SOA are also shown on the Van Krevelen diagrams in Fig. 2 (Panels b and c). Chhabra et al. (2010) found close agreement between the bulk elemental ratios measured by the AMS and those of compounds detected by offline GCMS by Yu et al. (1999), who were able to identify $>90 \%$ of the $\alpha$-pinene ozonolysis SOA mass. The species identified by Yu et al. (1999) are represented in Panel b by black squares and closely agree with AMS data. Peroxypinic acid, represented by the blue square, is a product of $\alpha$-pinene ozonolysis 
proposed by Docherty et al. (2005) and is an approximate O/C upper bound. Similar elemental compositions to those measured by the AMS have also been measured by other methods (Tolocka et al., 2006; Reinhardt et al., 2007).

Many of the same products identified in $\alpha$-pinene ozonolysis SOA have been identified in photooxidation SOA (Panel c) by Jaoui and Kamens (2001) (black circles), who determined that particle-phase products accounted for approximately $20 \%$ of the reacted carbon. Using their particlephase carbon yields, we calculate an average $\mathrm{H} / \mathrm{C}$ and $\mathrm{O} / \mathrm{C}$ ratio of 1.56 and 0.36 (represented by an orange square in Fig. 2, Panel c), closely agreeing with AMS measurements but slightly higher than those measured from FTIR analysis. Tri-carboxylic acid species (pink circle) observed in ambient aerosol filter samples have been proposed as photooxidation products of $\alpha$-pinene (Szmigielski et al., 2007), though it is unlikely the $\alpha$-pinene photooxidation experiments achieved $\mathrm{OH}$ exposures high enough to form these highly oxygenated species in substantial concentrations.

Since the publication of Yu et al. (1999) and Jaoui and Kamens (2001), several studies have identified oligoesters of $\alpha$-pinene photooxidation and ozonolysis products in the particle phase (Gao et al., 2004; Müller et al., 2008; Hall and Johnston, 2011). Gao et al. (2004) and Hall and Johnston (2011) have estimated oligomers to account for $50 \%$ of $\alpha$-pinene SOA mass. It is possible that sample work up in speciation studies hydrates oligomers, separating them into the identified monomers and moving them up the Van Krevelen diagram along a line of slope 2 . The original oligomers would reside further to the bottom left of the Van Krevelen diagram. As speciation of oligomers improves, the effect of oligomerization on the SOA elemental composition can be better constrained.

\subsection{Isoprene SOA}

The triangle and Van Krevelen plots for isoprenephotooxidation SOA appear in Fig. 3. The Van Krevelen diagram (Panel b) illustrates that the SOA elemental composition does not change appreciably over the course of the oxidation or at different $\mathrm{NO}_{\mathrm{x}}$ concentrations (Chhabra et al., 2010). However, $f_{44}$ increases as $f_{43}$ decreases over the course of the experiment for both $\mathrm{NO}_{\mathrm{x}}$ conditions (Panel a), suggesting that organic acid content increases with continued oxidation. High- $\mathrm{NO}_{\mathrm{x}}$ spectra also display higher $\mathrm{f}_{44}$ values than low- $\mathrm{NO}_{\mathrm{x}}$ spectra, consistent with filter measurements identifying methylglyceric acid oligomers as the dominant species in high- $\mathrm{NO}_{\mathrm{x}} \mathrm{SOA}$ and non-acid methyltetrols as the dominant species in low- $\mathrm{NO}_{\mathrm{x}}$ SOA. Panel a shows that data for both systems migrate to the top of the triangle with continued photooxidation.

The main species and classes of compounds identified in isoprene SOA under both high- $\mathrm{NO}_{\mathrm{x}}$ and low- $\mathrm{NO}_{\mathrm{x}}$ conditions are shown in Fig. 3, Panel b (Surratt et al., 2010; GomezGonzalez et al., 2008; Szmigielski et al., 2007; Surratt et al.,
2007, 2006; Claeys et al., 2004; Wang et al., 2005). Surratt et al. (2006) found that under low- $\mathrm{NO}_{\mathrm{x}}$ conditions, $\sim 25-$ $30 \%$ of the SOA mass in seeded experiments is organic peroxides, and under high- $\mathrm{NO}_{\mathrm{x}}$ conditions, oligomers comprise $\sim 22-34 \%$ of the SOA mass. Oligomerization of both methyltetrols and methylglyceric acid (or peroxides and nitrates thereof) results in the loss of water, especially under low RH condtions and therefore leads to lower $\mathrm{H} / \mathrm{C}$ and $\mathrm{O} / \mathrm{C}$ ratios. Products resulting from the linear oligomerization of 2-methyltetrol, 2-methylglyceric acid, and 2-methylglyceric acid nitrate are shown in Fig. 3, Panel b with the oligomerization limits denoted with circles. The locations of the circles highlight the importance of oligomerization in the isoprene system by suggesting that the elemental composition measured by the AMS represents that of highly oligomerized compounds rather than individual monomers or dimers; even better agreement between oligomers and AMS data is possible if one considers crosslinked oligomerization and other dehydration reactions. This observation is consistent with Dommen et al. (2006) who, based on volatility tandem differential mobility analyzer (VTDMA) measurements, found that under lower humidities isoprene SOA volatility is decreased, suggesting the effect of oligomerization.

\subsection{Monoaromatic SOA}

Figure 4 presents both diagrams for toluene and $m$-xylene photooxidation SOA. Like isoprene and $\alpha$-pinene photooxidation SOA, toluene and $m$-xylene SOA spectra sit on the right side of the triangle and migrate upwards, likely representing an increase in organic acid content and a decrease in non-acid oxygenates, possibly unsaturated carbonyls. This is consistent with studies showing small organic acids as a major aromatic SOA product (Fisseha et al., 2004). Increasing SOA oxygenation is also apparent in the Van Krevlen diagram as the AMS data show decreasing $\mathrm{H} / \mathrm{C}$ ratios and increasing $\mathrm{O} / \mathrm{C}$ ratios with continued oxidation. In addition, both plots show that $m$-xylene SOA is less oxidized than toluene SOA due to the presence of the second methyl group in $m$-xylene.

Structures of identified SOA products from toluene photooxidation are indicated in the Van Krevelen diagram Fig. 4, (Panel b) (Forstner et al., 1997; Hamilton et al., 2005; Sato et al., 2007; Fisseha et al., 2004; Edney et al., 2003; Kleindienst et al., 2004). Despite numerous studies investigating the aerosol composition of aromatic SOA, substantial mass closure has been difficult to achieve. For instance Forstner et al. (1997) studied the molecular composition of SOA formed from the photooxidation of several aromatic compounds and could quantify only $15-30 \%$ of the aerosol mass. In subsequent studies, typically $1 \%$ of toluene SOA could be identified (Hamilton et al., 2005; Sato et al., 2007). A study by Fisseha et al. (2004) determined 20-45\% of SOA from trimethylbenzene photooxidation were small organic acids. The uncertainty in the composition of aromatic SOA 

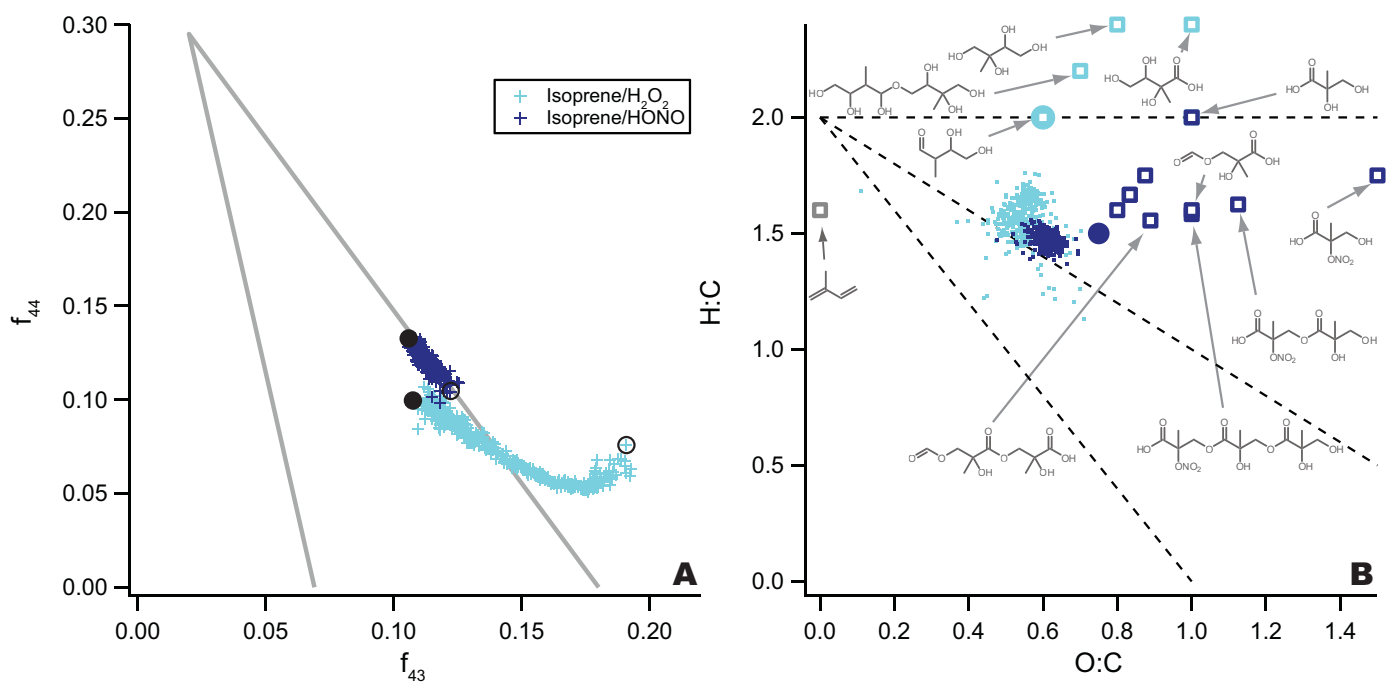

Fig. 3. (A) "Triangle plot" for SOA formed from photooxidation of isoprene under low- and high-NO $\mathrm{N}_{\mathrm{x}}$ conditions. Open and closed black circles represent the beginning and end of the experiments, respectively. (B) Van Krevelen diagram for SOA formed from photooxidation of isoprene under low- and high- $\mathrm{NO}_{\mathrm{x}}$ conditions Identified $\mathrm{SOA}$ products of each $\mathrm{NO}_{\mathrm{x}}$ condition are presented in blue boxes of the corresponding color (Surratt et al., 2006; Claeys et al., 2004; Wang et al., 2005; Surratt et al., 2007; Gomez-Gonzalez et al., 2008). Surratt et al. (2006) found that under low- $\mathrm{NO}_{\mathrm{x}}$ conditions, $\sim 25-30 \%$ of the SOA mass in seeded experiments is organic peroxides, and under high- $\mathrm{NO}_{\mathrm{x}}$ conditions, oligomers comprise $\sim 22-34 \%$ of the SOA mass. Oligomeric limits for each $\mathrm{NO}_{\mathrm{x}}$ condition are represented by circles.
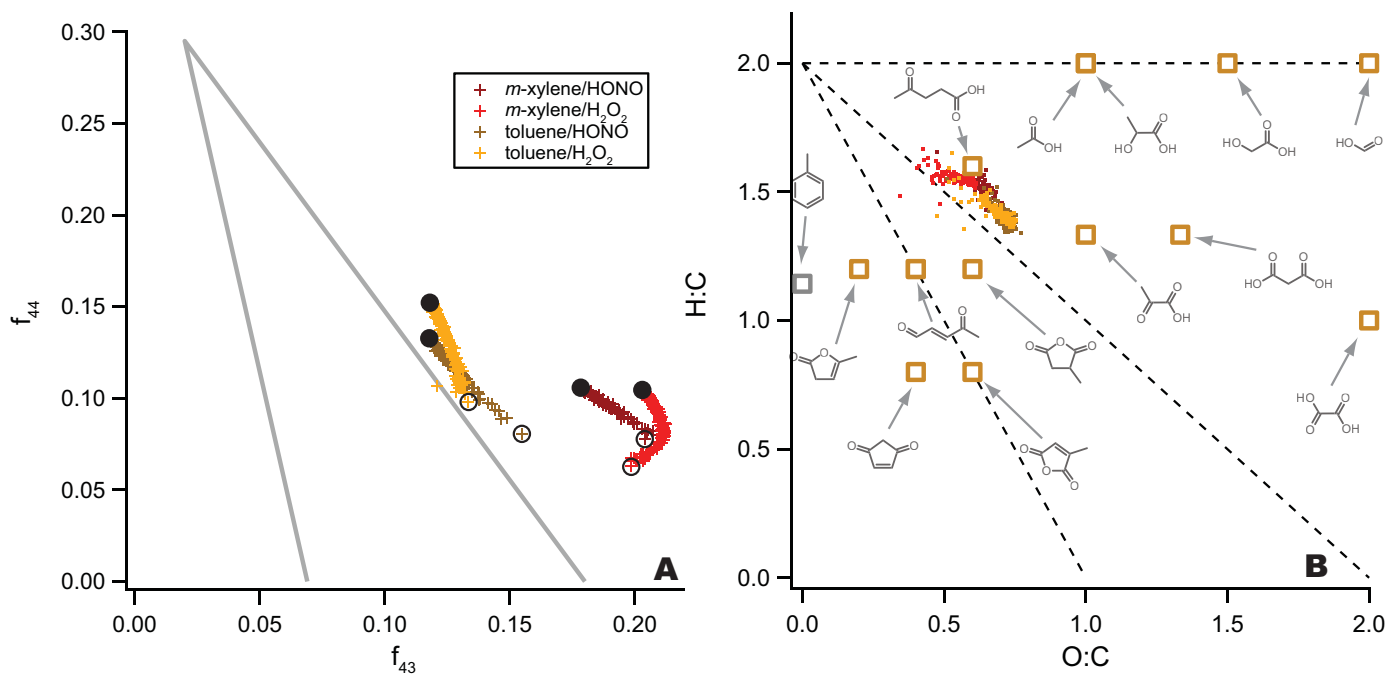

Fig. 4. (A) "Triangle plot" for SOA formed from photooxidation of toluene and $m$-xylene under low- and high-NO $\mathrm{N}_{\mathrm{x}}$ conditions. Open and closed black circles represent the beginning and end of the experiments, respectively. (B) Van Krevelen diagram for SOA formed from photooxidation of isoprene under low- and high- $\mathrm{NO}_{\mathrm{x}}$ conditions. Identified toluene-SOA products are presented in tan boxes (Sato et al., 2007; Hamilton et al., 2005; Bloss et al., 2005; Fisseha et al., 2004; Jang and Kamens, 2001; Kleindienst et al., 2004; Edney et al., 2003). Substantial mass closure has been difficult to achieve in molecular characterization studies.

is illustrated by the wide spread of SOA products around the AMS data and the absence of a clear representative compound or process explaining the measured elemental composition. AMS measurements indicate SOA that is less oxidized than the indicated compounds would suggest. How- ever, many of the small acids and carbonyls towards the top of Fig. 4, Panel b, are quite volatile and could represent monomers that have hydrated due to sample analysis. Similarly, compounds towards the bottom left of the figure are anhydrides that may have formed from sample work up. 

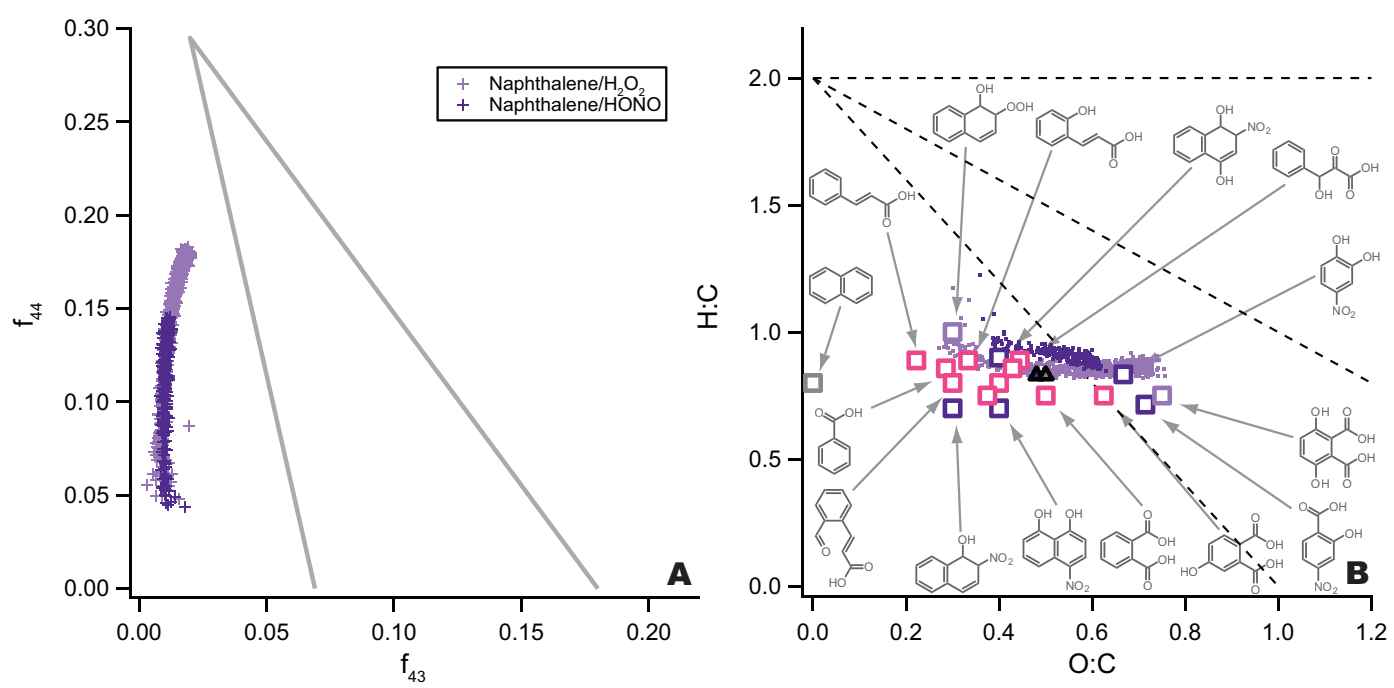

Fig. 5. (A) "Triangle" plot for SOA formed from photooxidation of naphthalene under low- and high-NO $\mathrm{N}_{\mathrm{x}}$ conditions. Experiment progression is from bottom to top. (B) Van Krevelen diagram for SOA formed from photooxidation of isoprene under low- and high-NO $\mathrm{N}_{\mathrm{x}}$ conditions. Identified SOA products of high-, low-, and both $\mathrm{NO}_{\mathrm{x}}$ conditions are presented in dark purple, light purple, and pink boxes, respectively (Kautzman et al., 2009). The mass weighted average $\mathrm{H} / \mathrm{C}$ and $\mathrm{O} / \mathrm{C}$ at each $\mathrm{NO}_{\mathrm{x}}$ condition are represented by triangles of the same color. Kautzman et al. (2009) were able to chemically characterize $53-68 \%$ of the SOA mass.

This could explain the divergence from AMS data in the Van Krevelen diagram manifested as movement up or down along a line of slope 2 .

\subsection{Naphthalene SOA}

Figure 5 presents the Van Krevelen and "triangle plots" for naphthalene photooxidation SOA. In contrast to the preceeding SOA systems, naphthalene AMS data lie to the left of the "triangle plot" and migrate straight upwards (Panel a), consistent with elemental AMS measurements on the Van Krevelen diagram which show increasing $\mathrm{O} / \mathrm{C}$ ratios (Panel b). The aromaticity of naphthalene allows for multiple oxidation pathways, including bicyclic peroxy radical and ringopening routes that lead to substantial organic acid yields. Kautzman et al. (2009) determined that about $16 \%$ of SOA formed under high- $\mathrm{NO}_{\mathrm{x}}$ conditions and $33 \%$ of SOA formed under low- $\mathrm{NO}_{\mathrm{x}}$ conditions are organic acids. Higher organic acid concentrations under low- $\mathrm{NO}_{\mathrm{x}}$ conditions are also consistent with AMS data which exhibit higher $\mathrm{f}_{44}$ values and $\mathrm{O} / \mathrm{C}$ ratios than those of high- $\mathrm{NO}_{\mathrm{x}}$ data, likely a result of higher $\mathrm{OH}$ exposures (Chhabra et al., 2010).

Structures of SOA products identified by Kautzman et al. (2009) in naphthalene SOA and their elemental compositions are presented in Fig. 5, Panel b. Kautzman et al. (2009) were able to chemically characterize $53-68 \%$ of the SOA mass and Chhabra et al. (2010) found close agreement between the elemental ratios of compounds identified and bulk ratios determined by AMS analysis. The mass weighted elemental compositions of naphthalene SOA formed under low and high $\mathrm{NO}_{\mathrm{x}}$ conditions as measured by filter analysis is represented by light and dark purple triangles, respectively. Oxygen-to-carbon ratios of identified species also span a range similar to that of AMS measurements of low$\mathrm{NO}_{\mathrm{x}}$ SOA, evidence of continuous aging.

\subsection{Phenol and methoxyphenol SOA}

Phenol and methoxyphenol compounds have been investigated as they are semivolatile species formed from the pyrolysis of lignin, the dominant process in biomass burning. Hawthorne et al. (1992) found that phenols and methoxyphenols accounted for forming $21 \%$ and $45 \%$ of aerosol mass from wood smoke, respectively. Like naphthalene SOA, phenol and methoxyphenol SOA lie to the left of the "triangle" with the highest $\mathrm{f}_{44}$ values of any precursor studied (Fig. 6a). Similarly, O/C ratios of methoxyphenols range from 0.8 to 1.0; syringol $\mathrm{SOA}$ achieves the highest $\mathrm{O} / \mathrm{C}$ ratios measured for any chamber aerosol precusor system. The $\mathrm{O} / \mathrm{C}$ values measured here are in close agreement with those of compounds formed in aqueous reactions of phenolic compounds (Sun et al., 2010). Addition of methoxy groups to the phenol ring increases the $\mathrm{H} / \mathrm{C}$ but tends to lead to decreases of the $\mathrm{f}_{44}$ of the resulting SOA. The presence of methoxy groups, while increasing the bulk oxygenation of SOA, may be retained in the SOA and inhibit acid formation.

Proposed structures of detected SOA products from guaiacol photooxidation are indicated in the Van Krevelen diagram (Fig. 6, Panel b). AMS measured elemental composition of SOA generated under high and low- $\mathrm{NO}_{\mathrm{x}}$ regimes 

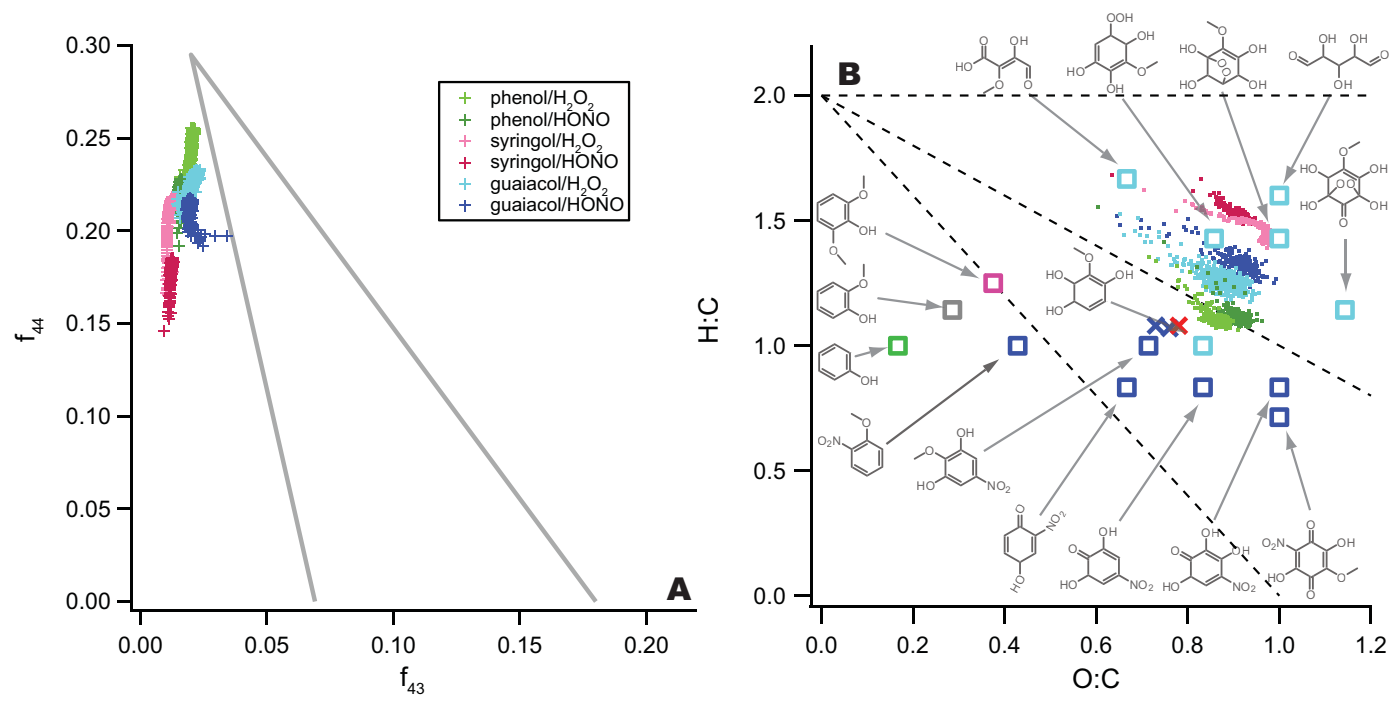

Fig. 6. (a) "Triangle plot" for SOA formed from photooxidation of phenol, guaiacol, and syringol under low- and high-NO $\mathrm{x}$ conditions. Experiment progression is from bottom to top. (B) Van Krevelen diagram for SOA formed from photooxidation of phenol, guaiacol, and syringol under low- and high- $\mathrm{NO}_{\mathrm{x}}$ conditions. Identified guaiacol-SOA products of high- and low- $\mathrm{NO}_{\mathrm{x}}$ conditions are presented dark and light blue boxes respectively. Elemental ratios as measured by FTIR data are represented by red (low- $\left.\mathrm{NO}_{\mathrm{x}}\right)$ and blue $\left(\right.$ high-NO $\left.\mathrm{X}_{\mathrm{x}}\right) \mathrm{crosses}$. Quantification of molecular species in methoxyphenol SOA systems has not yet been accomplished.

generally agree with the proposed compounds formed under low- $\mathrm{NO}_{\mathrm{x}}$ conditions but have higher $\mathrm{H} / \mathrm{C}$ ratios than those of compounds formed under high- $\mathrm{NO}_{\mathrm{x}}$ conditions. It is possible that the UPLC-MS techniques generally used in conjunction with filter sampling is biased to detect the high- $\mathrm{NO}_{\mathrm{x}}$ compounds shown, compounds with lower $\mathrm{H} / \mathrm{C}$ ratios. It is also possible that much of the SOA mass remains unmeasured by the UPLC-MS technique as much of the SOA could be in the form of small ring opened products (and their oligomers) such as those measured in monoaromatic SOA. This is supported by the large oxygen contribution in $\mathrm{CO}_{2}^{+}$(and other associated ions) in high-resolution AMS spectra as will be discussed in Sect. 3.8.

The FTIR elemental analysis underestimates $\mathrm{O} / \mathrm{C}$ as compared to the AMS elemental analysis. This maybe a result of the O/C constraint (as described in the Supplement) that is used to parameterize guaiacol SOA changing with oxidation. It is likely that the true parameterization lies somewhere between the ambient case and the precursor-specific case.

\subsection{Unsaturated aldehyde SOA}

Aldehdyes are widely formed in the atmospheric oxidation of SOA precursors; methacrolein is a gas-phase product of the high- $\mathrm{NO}_{\mathrm{x}}$ photooxidation of isoprene. Recent studies have shown that aldehydes are important intermediates to SOA formation and sensitive to $\mathrm{NO}$ and $\mathrm{NO}_{2}$ concentrations (Chan et al., 2010; Surratt et al., 2010). The "triangle plot" and Van Krevelen Diagram for SOA formed from the high$\mathrm{NO}_{\mathrm{x}}$ photooxidation of methacrolein, acrolein, and croton- aldehyde are given in Fig. 7. As shown in Fig. 1, crotonaldehyde and methacrolein are structural isomers of each other while acrolein lacks the additional methyl group. SOA from all three precursors cluster high in the "triangle plot" with acrolein having the highest $\mathrm{f}_{44}$ values. Such high oxidation states are likely due to carboxylic acids and esters contributing a larger fraction of the OA mass. This is consistent with acrolein SOA exhibiting the highest $\mathrm{O} / \mathrm{C}$ ratios $(\sim 0.8)$ of the three systems. SOA from methacrolein photooxidation has higher $\mathrm{f}_{43}$ values than that of crotonaldehyde SOA, implying that the position of the methyl group on the oligomeric chain affects fragmentation in the AMS, but does not change the elemental composiition of the SOA substantially.

Oligomers identified in crotonaldehyde and acrolein SOA are depicted in Fig. 7, Panel b. The monomers and oligomers formed from methacrolein photooxidation are the same as those of high- $\mathrm{NO}_{\mathrm{x}}$ isoprene SOA (Surratt et al., 2010). Like isoprene SOA, the addition of each monomer to the oligomeric chain results in the loss of a water molecule. The elemental composition of the limit of a linear oligomer is represented by a circle and approaches the AMS measurement suggesting that the AMS measurement is that of a highly esterified compound rather than individual monomers. As in the isoprene case, the lower $\mathrm{O} / \mathrm{C}$ ratios measured by the AMS is likely due to the inability of the AMS to efficiently detect oxygen in an organic nitrate group (Farmer et al., 2010; Rollins et al., 2010) as discussed in Sect. 3.9. 

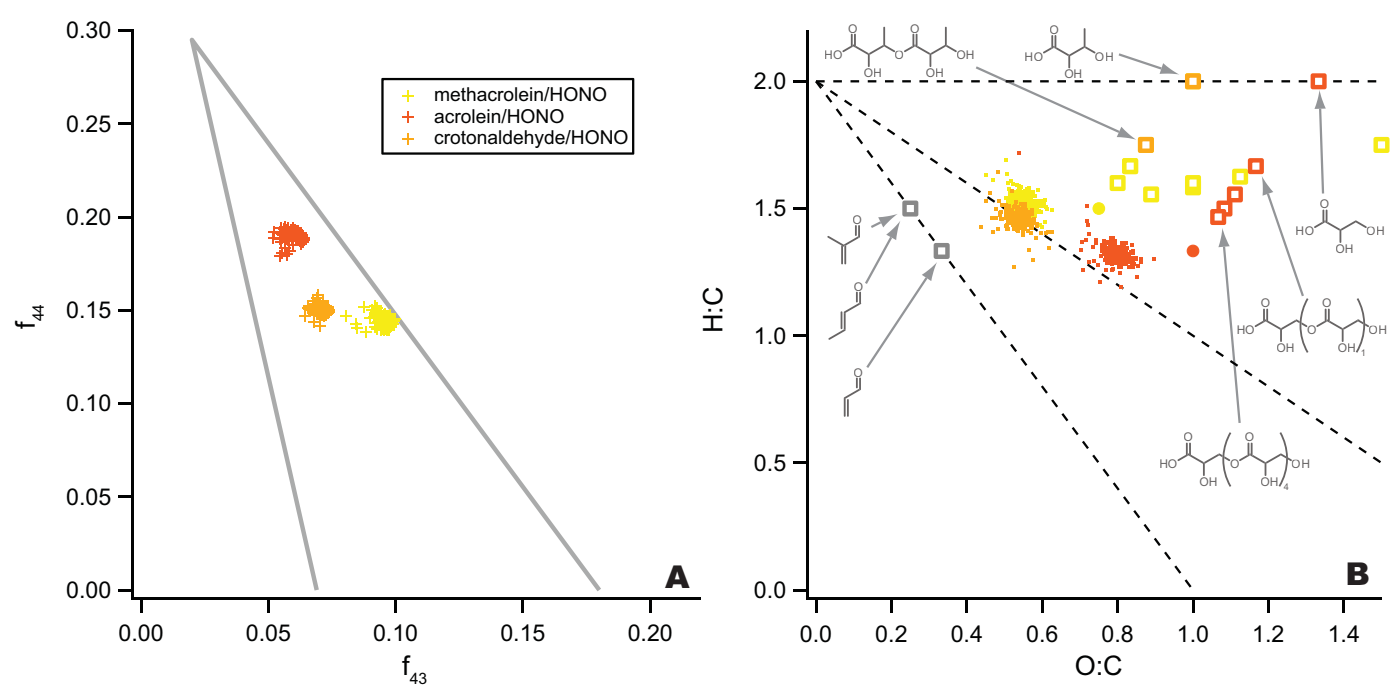

Fig. 7. (A) "Triangle plot" for SOA formed from photooxidation of methacrolein, acrolein, and crotonaldehyde. (B) Van Krevelen diagram for SOA formed from photooxidation of methacrolein, acrolein, and crotonaldehyde. Identified SOA products of each system are presented in boxes of the corresponding color (Chan et al., 2010). Oligomeric limits for each system condition are represented by circles.

\subsection{SOA from reactive uptake of glyoxal}

The reactive uptake of glyoxal onto ammonium sulfate aerosol and the elemental composition of its OA have been described in previous investigations (Galloway et al., 2009; Chhabra et al., 2010). Glyoxal OA exhibits high O/C ratios due to its high oxygen content and its ability to hydrate and polymerize in the aerosol phase (Fig. 8, Panel b). Despite a high measured $\mathrm{O} / \mathrm{C}$ ratio, glyoxal OA sits on the bottom left of the "triangle plot", a result of insignificant signals at $\mathrm{m} / \mathrm{z}$ 43 and 44 . Most of the oxygen signal in glyoxal OA spectra resides in $\mathrm{m} / \mathrm{z} 29\left(\mathrm{CHO}^{+}\right), 30\left(\mathrm{CH}_{2} \mathrm{O}^{+}\right), 31\left(\mathrm{CH}_{3} \mathrm{O}^{+}\right)$, and $47\left(\mathrm{CH}_{3} \mathrm{O}_{2}{ }^{+}\right)$(Chhabra et al., 2010).

Structures proposed to form in the aqueous particle phase are shown in Panel b. Hydrated glyoxal has the highest O/C and $\mathrm{H} / \mathrm{C}$ values; with consecutive additions of glyoxal, water is removed and the oligomer follows a dehydration route with a limit at the same elemental composition of glyoxal itself. Also shown on the Van Krevelen plot is 1H-imidazole2-carboxaldeyhde, a compound formed from the reaction of glyoxal with ammonium (Chhabra et al., 2010). The AMS elemental composition measurement lies roughly in the middle of the wide range spanned by the proposed species. Further work is needed in characterizing glyoxal OA, its interaction with inorganic species, and the extent of its oligomerization in SOA.

\subsection{Oxygen contribution in organonitrate and acid functional groups}

Having measurements of the chemical composition of oxidized SOA from different analytical techniques allows for a rich comparison of the oxygen contribution from differ- ent functional groups. Table 2 summarizes the fraction of oxygen originating from organonitrate and organic acid functionality in SOA formed at the end of oxidation experiments as determined by AMS, FTIR and speciation techniques. The oxygen contribution to organic acids groups in highresolution AMS data was calculated by determining the total oxygen mass measured at $\mathrm{CO}_{2}^{+}$as well as those ions dependent on the $\mathrm{CO}_{2}^{+}$signal through the fragmentation table, $\mathrm{O}^{+}$, $\mathrm{HO}^{+}, \mathrm{H}_{2} \mathrm{O}^{+}$, and $\mathrm{CO}^{+}$(Aiken et al., 2008). The oxygen contribution to organic nitrate groups in AMS data was determined from the total oxygen contribution at $\mathrm{NO}_{\mathrm{x}}$ family ions, $\mathrm{NO}^{+}$and $\mathrm{NO}_{2}^{+}$. Oxygen contribution in acid and nitrate groups are calculated from FTIR measurements by multiplying the measured functional group mass by the mass fraction of oxygen in the group. Contributions of oxygen in speciation studies are calculated similarly but on a species basis.

Table 2 shows that the FTIR, AMS and speciation techniques find that naphthalene and methoxyphenol systems have the greatest fraction of total SOA oxygen in organic acid groups. High-resolution AMS data find that 65-72\% of oxygen signal can be found at acid associated ions in naphthalene SOA formed under high and low- $\mathrm{NO}_{\mathrm{x}}$ conditions, respectively. This is in fair agreement with Kautzman et al. (2009) who found $73-81 \%$ of speciated oxygen is contained in acid groups. Further investigation of the AMS data of naphthalene high- $\mathrm{NO}_{\mathrm{x}} \mathrm{SOA}$ shows that at the peak of SOA growth, the acid-oxygen contribution is only $41 \%$ while the nitrate-oxygen contribution is $22 \%$. As oxidation continues, the contribution of nitrate-oxygen decreases significantly to $6 \%$ while the acid fraction increases to $65 \%$, as listed in Table 2 . These observations are supported by the data and structures in Fig. 5. SOA formed under both conditions exhibit a 

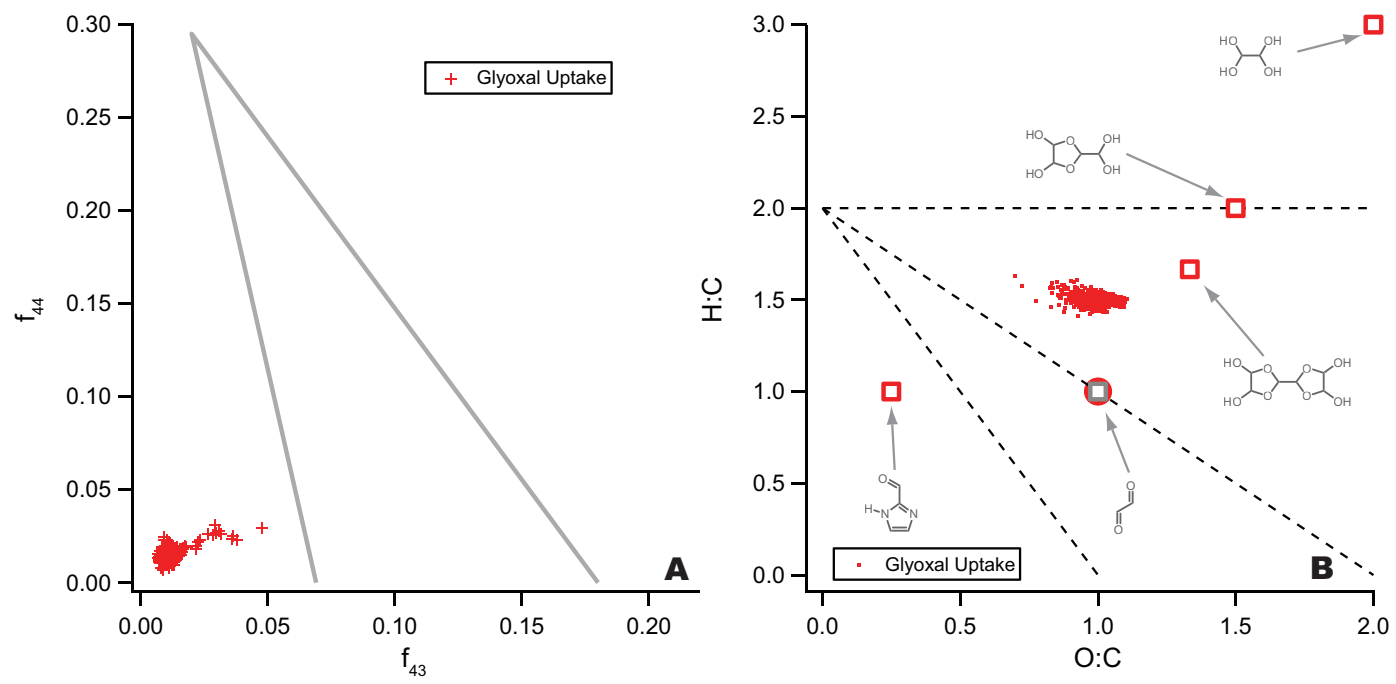

Fig. 8. (A) "Triangle plot" for SOA formed from reactive uptake of glyoxal onto wet ammonium sulfate aerosol. (B) Van Krevelen diagram for SOA formed from the uptake of glyoxal onto wet ammonium sulfate aerosol. Proposed SOA products are presented in boxes (Galloway et al., 2009; Kua et al., 2008; Loeffler et al., 2006). Oligomeric limits for glyoxal oligomerization condition is represented by a circle.

steady increase in $\mathrm{f}_{44}$ in Panel a and structures in Panel b are overwhelmingly acid while the nitronaphthalene compounds appear at lower $\mathrm{O} / \mathrm{C}$ ratios corresponding to lower irradiation times. It is possible that under high- $\mathrm{NO}_{\mathrm{x}}$ conditions, nitronaphthalene compounds are formed initially but react further to remove nitrogen functionality and add acid functionality. FTIR and AMS data also find significant contributions of oxygen in acid functional groups in guaiacol SOA and relatively small fraction of oxygen in nitrate groups. As was mentioned in Sect. 3.5, much of the SOA could be in the form of small ring-opening products that are typically difficult to separate and identify using UPLC-MS techniques.

In contrast, FTIR and AMS high-resolution data measures significantly less oxygen in acid groups than what was determined from the characterization performed by $\mathrm{Yu}$ et al. (1999) and Jaoui and Kamens (2001) for the $\alpha$-pinene SOA systems. The greatest discrepancy occurs for photooxidation SOA where 31 to $40 \%$ of the AMS measured oxygen occurs at acid associated ions while Jaoui and Kamens (2001) find the fraction of oxygen in acid groups to be $70 \%$. However, Jaoui and Kamens (2001) do not identify any organonitrates compounds. If the contribution of nitrate-oxygen is removed in FTIR and AMS data, the comparison improves; the FTIR and AMS acid-oxygen contributions become $50 \%$ and $36 \%$. It is possible that organonitrates may have gone undetected in the characterization performed by Jaoui and Kamens (2001) either through loss in sample work up or poor sensitivity in the GC-EIMS technique used.
The AMS measures a greater contribution of oxygen in acid associated ions for isoprene SOA formed under high$\mathrm{NO}_{\mathrm{x}}$ conditions than under low- $\mathrm{NO}_{\mathrm{x}}$ conditions. This can be explained by the abundance of methyl glyceric acids and oligoesters detected in high- $\mathrm{NO}_{\mathrm{x}} \mathrm{SOA}$ as opposed to the tetrols and polyols in low- $\mathrm{NO}_{\mathrm{x}} \mathrm{SOA}$. In high- $\mathrm{NO}_{\mathrm{x}} \mathrm{SOA}$ spectra, nitrate ions contribute $8 \%$ of the total oxygen signal while nitrate groups in the structures depicted in Fig. 3, Panel b exhibit a much larger nitrate contribution. This is possibly explained by the inability of the AMS to fully detect oxygen in organonitrates compounds, as is discussed in Sect. 3.9. This would also explain the low contribution of oxygen in nitrate ions for the spectra of unsaturated aldehyde SOA. High-resolution AMS spectra exhibit an acid-oxygen contribution of $37-50 \%$ and a nitrate-oxygen contribution of $10-14 \%$ for monoaromatic SOA. While the oxygen fraction in nitrate ions decreases slightly over time, it still represents a significant contribution to the measured AMS O/C. It is possible that organic nitrogen is present in particle-phase ring-opening products that are not easily separated or identified through offline methods more work needs to be done to characterize aromatic SOA and determine what effect sample preparation and analysis can have on the measurement.

\subsection{AMS analysis uncertainty}

Much of the uncertainty in AMS analysis data can be attributed to the treatment of organonitrate compounds. In ambient data sets, nitrate is generally considered inorganic and therefore $\mathrm{NO}_{\mathrm{x}}$ family ions $\left(\mathrm{NO}^{+}\right.$and $\left.\mathrm{NO}_{2}^{+}\right)$are not included as part of the organic elemental analysis, possibly leading to underestimation of ambient SOA O/C values. Farmer et al. 
Table 2. Fraction SOA oxygen contribution in organic acid, organic nitrate, and other functionalities as measured by the AMS, FTIR, and speciation analyses.

\begin{tabular}{|c|c|c|c|c|}
\hline \multirow[b]{2}{*}{ SOA System } & \multirow[b]{2}{*}{ Measurement Method } & \multicolumn{3}{|c|}{ Oxygen Contribution } \\
\hline & & $\operatorname{Acid}^{\mathrm{a}}$ & Nitrate $^{b}$ & Other \\
\hline \multicolumn{5}{|c|}{$\alpha$-pinene ozonolysis } \\
\hline & AMS & 0.41 & 0.00 & 0.59 \\
\hline & Yu et al. (1999) & 0.58 & 0.00 & 0.42 \\
\hline \multicolumn{5}{|c|}{$\alpha$-pinene photooxidation } \\
\hline & AMS low- $\mathrm{NO}_{\mathrm{x}}$ & 0.31 & 0.00 & 0.69 \\
\hline & FTIR low- $\mathrm{NO}_{\mathrm{x}}$ & 0.31 & 0.00 & 0.69 \\
\hline & AMS high- $\mathrm{NO}_{\mathrm{x}}$ & 0.33 & 0.10 & 0.58 \\
\hline & FTIR high- $\mathrm{NO}_{\mathrm{x}}$ & 0.40 & 0.19 & 0.41 \\
\hline & Jaoui and Kamens (2001) & 0.70 & 0.00 & 0.30 \\
\hline \multicolumn{5}{|c|}{ isoprene photooxidation } \\
\hline & AMS low- $\mathrm{NO}_{\mathrm{x}}$ & 0.37 & 0.00 & 0.63 \\
\hline & AMS high- $\mathrm{NO}_{\mathrm{x}}$ & 0.45 & 0.09 & 0.47 \\
\hline \multicolumn{5}{|c|}{ monoaromatic photooxidation } \\
\hline & toluene AMS low- $\mathrm{NO}_{\mathrm{x}}$ & 0.50 & 0.00 & 0.50 \\
\hline & toluene AMS high $-\mathrm{NO}_{\mathrm{x}}$ & 0.42 & 0.10 & 0.48 \\
\hline & $m$-xylene AMS low- $\mathrm{NO}_{\mathrm{x}}$ & 0.37 & 0.00 & 0.63 \\
\hline & $m$-xylene AMS high- $\mathrm{NO}_{\mathrm{x}}$ & 0.36 & 0.14 & 0.49 \\
\hline \multicolumn{5}{|c|}{ naphthalene photooxidation } \\
\hline & AMS low- $\mathrm{NO}_{\mathrm{x}}$ & 0.72 & 0.00 & 0.28 \\
\hline & Kautzman et al. (2009) low- $\mathrm{NO}_{\mathrm{x}}$ & 0.82 & 0.00 & 0.18 \\
\hline & AMS high- $\mathrm{NO}_{\mathrm{x}}$ & 0.65 & 0.06 & 0.29 \\
\hline & Kautzman et al. (2009) high- $\mathrm{NO}_{\mathrm{x}}$ & 0.73 & 0.07 & 0.20 \\
\hline \multicolumn{5}{|c|}{ methoxyphenol photooxidation } \\
\hline & phenol AMS low- $\mathrm{NO}_{\mathrm{x}}$ & 0.77 & 0.00 & 0.23 \\
\hline & phenol AMS high- $\mathrm{NO}_{\mathrm{x}}$ & 0.69 & 0.04 & 0.27 \\
\hline & guaiacol AMS low- $\mathrm{NO}_{\mathrm{x}}$ & 0.61 & 0.00 & 0.39 \\
\hline & guaiacol FTIR low- $\mathrm{NO}_{\mathrm{x}}$ & 0.77 & 0.00 & 0.23 \\
\hline & guaiacol AMS high- $\mathrm{NO}_{\mathrm{x}}$ & 0.70 & 0.06 & 0.24 \\
\hline & guaiacol FTIR high- $\mathrm{NO}_{\mathrm{x}}$ & 0.82 & 0.01 & 0.18 \\
\hline & syringol AMS low- $\mathrm{NO}_{\mathrm{X}}$ & 0.59 & 0.00 & 0.41 \\
\hline & syringol AMS high- $\mathrm{NO}_{\mathrm{x}}$ & 0.54 & 0.04 & 0.42 \\
\hline \multicolumn{5}{|c|}{ unsaturated aldehyde photooxidation } \\
\hline & acrolein AMS high- $\mathrm{NO}_{\mathrm{x}}$ & 0.54 & 0.04 & 0.42 \\
\hline & methacrolein AMS high- $\mathrm{NO}_{\mathrm{x}}$ & 0.55 & 0.04 & 0.41 \\
\hline & crotonaldehyde AMS high- $\mathrm{NO}_{\mathrm{x}}$ & 0.50 & 0.03 & 0.47 \\
\hline
\end{tabular}

${ }^{\text {a }}$ Oxygen contribution to organic acids groups in high-resolution AMS data was calculated by determining the total organic oxygen mass measured at $\mathrm{CO}_{2}^{+}, \mathrm{O}^{+}, \mathrm{HO}^{+}, \mathrm{H}_{2} \mathrm{O}^{+}$, and $\mathrm{CO}^{+}$(Aiken et al., 2008).

${ }^{\mathrm{b}}$ Oxygen contribution to organic acids groups in high-resolution AMS data was calculated by determining the total oxygen mass measured at $\mathrm{NO}_{2}^{+}$and $\mathrm{NO}^{+}$.

(2010) estimated that for the Study of Organic Aerosols in Riverside (SOAR-1) ambient campaign, organonitrates contribute $5-10 \%$ of the total nitrate mass, though do not dominate AMS nitrate spectra. In the analysis of high- $\mathrm{NO}_{\mathrm{x}}$ cham- ber experiments in which the humidity is too low for nitrate acid to appreciably partition to the particle phase, categorizing $\mathrm{NO}_{\mathrm{x}}$ family ions as organic is an appropriate assumption to make. However, even when $\mathrm{NO}_{\mathrm{x}}$ family ions are included 
as part of the total organic mass spectra, their oxygen contribution tends to be underestimated due to the inability of the AMS to detect the nitrogen-bonded oxygen in the $-\mathrm{ONO}_{2}$ group (Farmer et al., 2010; Rollins et al., 2010). This may also occur for peroxides formed under low- $\mathrm{NO}_{\mathrm{x}}$ conditions; upon fragmentation the $\mathrm{RO}-\mathrm{OH}$ bond can sever leaving the $\mathrm{OH}$ fragment effectively undetected. This maybe a reason why SOA formed under different $\mathrm{NO}_{\mathrm{x}}$ regimes have similar elemental compositions. On average, inclusion of $\mathrm{NO}_{\mathrm{x}}$ family ions to the organic spectra increases the $\mathrm{O} / \mathrm{C}$ ratio of the systems studied by 0.05 , with $m$-xylene SOA having the largest difference of 0.10 and crotonaldehyde having the smallest difference of 0.02 . These contributions also tend to decrease as a function of experiment time. Thus, the relative formation of organonitrates is precursor and time dependent and, therefore, so is the contribution of $\mathrm{NO}_{\mathrm{x}}$ family ions to the O/C. However, these differences still fall within the uncertainty reported by Aiken et al. (2008). Organonitrate oxygen is included fully in the calculation of $\mathrm{O} / \mathrm{C}$ for speciated measurements. However, the detection and quantification of organonitrate compounds is again system dependent. Despite these limitations, we still see that for systems in which SOA can be chemically characterized well, the AMS and average speciated $\mathrm{O} / \mathrm{C}$ agree. As detection and quantification techniques of organonitrates improve, more robust comparisons between measurement techniques can be achieved, and the contribution of organic nitrogen to ambient SOA can be better constrained.

Another source of uncertainty is the calibration factors and fragmentation table ratios used to correct for ionization biases in AMS spectra and air contamination. The applied correction factors are based on a limited set of standards and have an inherent uncertainty (Aiken et al., 2008). As was discussed by Chhabra et al. (2010), these standards are large alkanols, alkanoic acids, and aromatic species that are similar to those detected in $\alpha$-pinene and naphthalene SOA. By contrast, few of the standards have structures similar to species found in isoprene and aromatic SOA like polyols and small acids. Kessler et al. (2010) has shown that for polyhydroxylated species, the default correction factor for $\mathrm{O} / \mathrm{C}$ underestimates $\mathrm{O} / \mathrm{C}$.

There is also uncertainty in the AMS fragmentation table particularly when determining the relative contribution of $\mathrm{CO}^{+}, \mathrm{H}_{2} \mathrm{O}^{+}$, and $\mathrm{CO}_{2}^{+}$ions in high-resolution spectra. As shown in the supplemental section, the ratio of organic $\mathrm{CO}^{+}$to $\mathrm{CO}_{2}^{+}$was found to be close to unity, the default fragmentation wave value based on Aiken et al. (2008), so this value was used. In a study by Chen et al. (2011), researchers determined fragmentation ratios much different than those measured by Aiken et al. (2008) for the isoprene low- $\mathrm{NO}_{\mathrm{x}}$ photooxidation system. Using those ratios to calculate $\mathrm{O} / \mathrm{C}$ ratios for the low- $\mathrm{NO}_{\mathrm{x}}$ isoprene $\mathrm{SOA}$ system presented here increases the $\mathrm{O} / \mathrm{C}$ by $57 \%$. More work is needed to constrain these ratios in both ambient and chamber environments.

\section{Discussion and conclusions}

We investigate two different analysis methods ("triangle plot" and Van Krevelen diagram) for representing the general processes of formation and aging of SOA. Figure 9 summarizes SOA data in a "triangle plot" and Van Krevelen diagram for the variety of laboratory systems studied. Despite the variety of experimental conditions, differences in oxidative conditions have relatively little effect on the spectral identity and elemental composition of SOA as measured by the AMS compared to the identity of the SOA precursor. Most SOA formed under high- and low- $\mathrm{NO}_{\mathrm{x}}$ conditions occupy similar areas in the "triangle plot" and Van Krevelen diagram. Typically, chemical characterizations of SOA find signficant concentrations of peroxides under low- $\mathrm{NO}_{\mathrm{x}}$ conditions and organic nitrates under high- $\mathrm{NO}_{\mathrm{x}}$ conditions. However, it is likely that these differences in functionality do not lead to substantial differences in $\mathrm{f}_{43}$ and $\mathrm{f}_{44}$ and the elemental composition as the underlying chemical structure of SOA remains relatively unchanged and because the AMS has difficulty in measuring oxygen that is lost in fragmented organic nitrate and peroxide functionality. All individual photooxidation systems, apart from the aldehydes whose carbon chain is too small to support continued oxidation without fragmentation into more volatile species, also show that AMS spectra head toward the top of the "triangle plot" as they age, consistent with an increase in $\mathrm{O} / \mathrm{C}$ ratios in the Van Krevelen diagram. Evidence from other AMS studies suggest that this movement toward the top of the "triangle plot" is representative of an increase in organic acids (Alfarra, 2004; Aiken et al., 2007; Takegawa et al., 2007; Duplissy et al., 2011).

We find general agreement between the $\mathrm{f}_{43}$ and $\mathrm{f}_{44}$ values presented in $\mathrm{Ng}$ et al. (2010) and those presented here for the traditional set of SOA systems: monoaromatic, $\alpha$-pinene, and isoprene SOA. In cases where $\mathrm{f}_{43}$ and $\mathrm{f}_{43}$ differ by more than $2 \%$ are possibly due to differences in organic loading; Shilling et al. (2009) found that $\mathrm{f}_{43}$ increased with increasing loading. Differences in $\mathrm{f}_{43}$ and $\mathrm{f}_{44}$ could also result from differences in vaporizer temperature leading to small differences in spectral signal at low $\mathrm{m} / \mathrm{z}$ These SOA systems cluster in the lower half of the "triangle plot" indicating relatively low oxygen content and a high degree of mass spectral variation, similar to SV-OOA components. The additional SOA precursors studied here exhibit more mass spectral variation and show that highly oxidized OA with similar O/C ratios to LV-OOA can be formed in a laboratory chamber. The most oxidized SOA formed in the systems studied here results from the photooxidation of already oxidized VOCs, methoxyphenols and unsaturated aldehydes, suggesting that $\mathrm{OH}$ exposure is the limiting variable in SOA oxidation. The $\mathrm{OH}$ exposure for the photooxidative experiments vary from 1 to $2 \times 10^{9}$ molec $\mathrm{cm}^{-3}$ min which is equivalent to approximately 1-2 days in the ambient atmosphere. In contrast, Lambe et al. (2011) report minimum and maximum $\mathrm{OH}$ exposures of $1 \times 10^{11}$ and $2 \times 10^{12} \mathrm{molec} \mathrm{cm}^{-3} \mathrm{~s}$, respectively, 

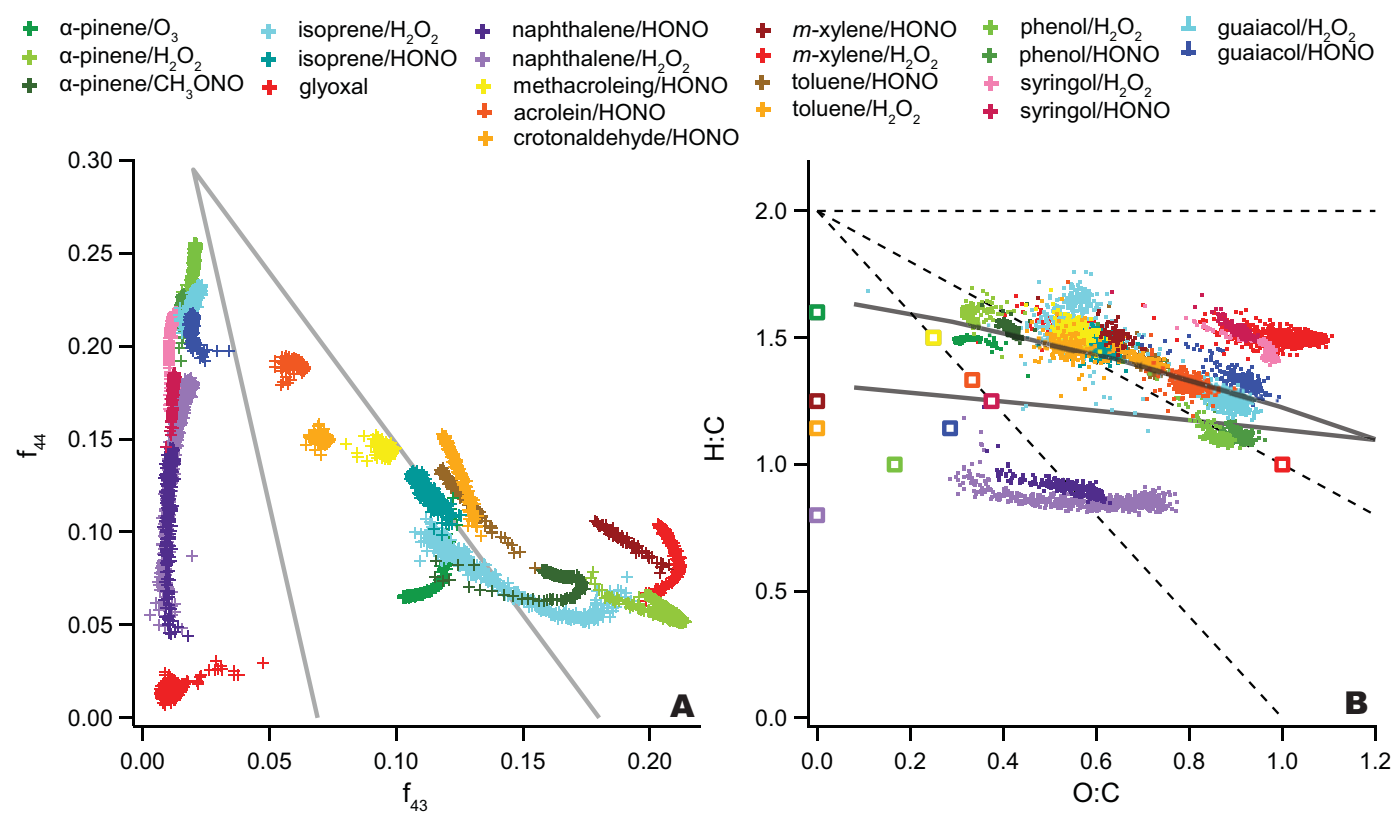

Fig. 9. (A) Triangle plot for all SOA systems (B) Van Krevelen diagram for all SOA systems. SOA precursors are represented by corresponding colored boxes. The "VK-triangle" parameterization developed by Ng et al. (2011) is represented by solid gray curves.

for Potential Aerosol Mass (PAM) flow tube experiments, corresponding to 1 to 23 days in the ambient atmosphere. The much higher $\mathrm{OH}$ exposures allow Lambe et al. (2011) to start with SOA at the bottom of the "triangle plot" and move all the way to the top. While $\mathrm{f}_{44}$ has the ability to increase significantly in chamber experiments (naphthalene for example), movement from the bottom of the triangle with a single precursor is not possible with the smaller $\mathrm{OH}$ exposures. To account for this, already oxidized precursors can be used as surrogates for creating highly oxidized SOA as seen in the methacrolein and isoprene high- $\mathrm{NO}_{\mathrm{x}}$ systems. Methacrolein, a gas-phase product and major SOA intermediate of isoprene photooxidation that forms when the isoprene hydroxyperoxy radical reacts with $\mathrm{NO}$, yields $\mathrm{SOA}$ with $\mathrm{f}_{43}$ and $\mathrm{f}_{44}$ values just beyond those of isoprene SOA range. It is likely that isoprene $\mathrm{SOA}$ formed under high- $\mathrm{NO}_{\mathrm{x}}$ conditions falls short of methacrolein SOA in the "triangle plot" because the isoprene SOA would also include products that form from $\mathrm{RO}_{2}$ $\mathrm{HO}_{2}$ reactions that occur at lower $\mathrm{NO}_{\mathrm{x}}$ concentrations. In the extreme case, methoxyphenol SOA simulates the continued oxidation of napthalene SOA and is subject to multiple oxidation steps on an already oxidized compound, leading to $\mathrm{O} / \mathrm{C}$ ratios that approach unity. Although containing aromatic functionality, both methoxyphenols and naphthalene generate SOA spectra that group on the left side of the "triangle plot" while $m$-xylene and toluene generate SOA spectra that group on the right side. Similarly, Ng et al. (2010) found that benzene SOA spectra sit on the left side of the "triangle plot" and 1,3,5-trimethylbenzene SOA spectra sit on the right. It is likely that functionality on the aromatic ring of the SOA precursor affects the fragmentation of the resultant SOA. Specifically, groups like $-\mathrm{CH}_{3}$ on the aromatic ring yield SOA spectra with high $\mathrm{f}_{43}$ values while electron donating groups like $-\mathrm{OH}$ and $-\mathrm{OCH}_{3}$ or the lack of functionality on the aromatic ring yield SOA spectra with low $\mathrm{f}_{43}$ values. Table 2 shows that while nitrate and acid groups contain much of the oxygen in oxidized SOA, a similar fraction remains in other ions such as $\mathrm{C}_{2} \mathrm{H}_{3} \mathrm{O}^{+}$at $m / z$ 43. More work needs to be done to quantify these non-acid, non-nitrate oxygenated functionalities and determine how they fragment to form AMS spectra.

Figure 9, Panel b demonstrates that change in elemental composition that occurs from SOA precursor to SOA is a function of the precursor identity and structure. $\alpha$-pinene ozonolysis SOA exhibits the smallest change in $\mathrm{O} / \mathrm{C}$ because ozone is only reactive to alkene functionality, and once the double bond in $\alpha$-pinene has reacted, the potential for aging through ozonolysis is halted. $\mathrm{OH}$ radicals will react with saturated aliphatic carbon but to a much lesser extent than alkene functionality so further oxidation is dramatically slowed. Aromatics, however, show much greater potential for increases in $\mathrm{O} / \mathrm{C}$ because aromaticity allows many more oxidative steps starting with $\mathrm{OH}$ attack to bicyclic radical formation, to ring cleaving. Both naphthalene and phenol undergo large changes in $\mathrm{O} / \mathrm{C}$ as the unsaturated rings add oxygen. In the case of naphthalene, H:C remains low because $\mathrm{OH}$ cleaves one ring at a time leaving one aromatic ring intact. For phenol, the $\mathrm{H}: \mathrm{C}$ is higher due to the fact 
that the monoaromatic ring opens allowing for $\mathrm{OH}$ radicals to saturate double bonds.

The Van Krevelen diagrams of the elemental composition of individual SOA systems reveal that elemental ratios measured by the AMS agree most closely with SOA systems for which the greatest degree of mass closure has been achieved, within the uncertainty of the AMS elemental analysis. Yu et al. (1999) were able to speciate $>90 \%$ of the $\alpha$ pinene ozonolysis aerosol composition by mass, and Kautzman et al. (2009) were able to characterize $53-68 \%$ of the SOA formed from naphthalene photooxidation, the two systems with the closest agreement between measured elemental ratios and identified compounds. The diagrams also illustrate that highly oligomerized compounds may dominate, in particular, SOA systems such as isoprene and unsaturated aldehyde photooxidation. Conversely, in systems for which mass closure has been difficult, such as monoaromatics, AMS and filter data do not agree.

From a variety of ambient and laboratory measurements, Heald et al. (2010) found that atmospheric OA occupy a narrow range in the Van Krevelen diagram following a line with slope of -1 implying the addition of carboxylic acids or equal amounts of hydroxy and carbonyl functional groups on average to a saturated carbon chain. From Fig. 9, Panel b, the set of SOA systems on the Van Krevelen diagram tend to map a slope shallower than -1 . In the systems studied here, most SOA precursors do not resemble a saturated chain, and many have cyclic chains, alkene, or aromatic groups. This allows for oxidation of the precursor without substantial loss of hydrogen, leading to a slope shallower than -1 , even with the addition of carbonyl and acid groups. Aging pathways on the Van Krevelen diagram are likely to be different for different precursor species like isoprene and $\alpha$-pinene and for different precursor classes like biogenic and anthropogenic VOCs. Recently Ng et al. (2011) developed a parameterization to transform ambient OOA components in the "triangle plot" directly onto the Van Krevelen space. The transformed ambient "VK-triangle" (shown in Fig. 9, Panel b) is consistent with the chamber data and also yields a slope shallower than -1 .

Figure 9, Panel a shows that precursor structure and functionality determine the SOA "starting point" on the "triangle plot" and that the path taken is largely dependent on identity of the SOA precursor. $\mathrm{Ng}$ et al. (2010) showed that as SOA photochemically ages, and becomes more oxidized, spectral uniqueness is lost and SOA on the "triangle plot" becomes chemically similar. Panel a supports this model with higher $\mathrm{f}_{44}$ values correlating with increased SOA oxygenation and a tendency for SOA to converge towards the peak of the triangle, which corresponds to an oxidation state $\left(\overline{\mathrm{OS}_{\mathrm{C}}} \approx 2 \times \mathrm{O} / \mathrm{C}-\mathrm{H} / \mathrm{C}\right)$ (Kroll et al., 2011) of around 1 (Ng et al., 2011; Kroll et al., 2011). Panel a also shows that with a finite set of SOA precursors, one can essentially recreate the "triangle plot" as originally created by $\mathrm{Ng}$ et al. (2010). The SOA spectra represented on the boundaries of the trian- gle do not mean that they are not representative of ambient spectral components nor do they represent the spectral extremes of chamber SOA as the complete set of SOA precursors is far from being known. Rather this SOA lies along the outlines of the triangle depicted by Ng et al. (2010). Ambient spectra and components falling within the triangle represent the ensemble average of many different SOA precursors and oxidative processes that mix spatially and temporally. And as SOA becomes more oxidized, it loses its source history. Recently, work by Lee et al. (2011) show that oxidized solutions of pinonic acid, glyoxal and SOA from laboratory and ambient sources map out a larger triangular area than what was depicted by $\mathrm{Ng}$ et al. (2010) and that mixing aerosol sources also mixed their spectra signals. Additionally, Lambe et al. (2011) show that the "triangle plot" could be expanded with Potential Aerosol Mass measurements, and those systems that individually lie on the edges of the triangle could be mixed to form SOA that falls in the center of the triangle. Indeed more chamber experiments would help to more fully characterize the "triangle plot" space. Highresolution analysis with species identification can more accurately assign functional groups to individual ions in the AMS spectra. Molecular level chemical characterization of SOA will also be useful in comparison to AMS elemental measurements, especially in systems for which mass closure has been difficult.

\section{Supplementary material related to this article is available online at: http://www.atmos-chem-phys.net/11/8827/2011/ acp-11-8827-2011-supplement.pdf.}

Acknowledgements. This work was supported by the US Department of Energy Biological and Environmental Research grant DE-FG02-05ER63983, US Environmental Protection Agency STAR grant RD-83374901, and US NSF grant ATM-0432377. It has not been formally reviewed by EPA. The views expressed in this document are solely those of the authors and the EPA does not endorse any products in this publication. The authors would like to thank Christine Loza for SOA yield analysis and Man Nin Chan, Lindsay Yee, and Katherine Schilling for guaiacol filter analysis. The authors would also like to thank Satoshi Takahama for helpful discussions on FTIR analysis.

Edited by: G. McFiggans

\section{References}

Aiken, A. C., DeCarlo, P. F., and Jimenez, J. L.: Elemental analysis of organic species with electron ionization highresolution mass spectrometry, Anal. Chem., 79, 8350-8358, doi:10.1021/Ac071150w, 2007.

Aiken, A. C., Decarlo, P. F., Kroll, J. H., Worsnop, D. R., Huffman, J. A., Docherty, K. S., Ulbrich, I. M., Mohr, C., Kimmel, J. R., Sueper, D., Sun, Y., Zhang, Q., Trimborn, A., Northway, 
M., Ziemann, P. J., Canagaratna, M. R., Onasch, T. B., Alfarra, M. R., Prevot, A. S. H., Dommen, J., Duplissy, J., Metzger, A., Baltensperger, U., and Jimenez, J. L.: O/C and OM/OC ratios of primary, secondary, and ambient organic aerosols with high-resolution time-of-flight aerosol mass spectrometry, Environ. Sci. Technol., 42, 4478-4485, doi:10.1021/Es703009q, 2008.

Aiken, A. C., Salcedo, D., Cubison, M. J., Huffman, J. A., DeCarlo, P. F., Ulbrich, I. M., Docherty, K. S., Sueper, D., Kimmel, J. R., Worsnop, D. R., Trimborn, A., Northway, M., Stone, E. A., Schauer, J. J., Volkamer, R. M., Fortner, E., de Foy, B., Wang, J., Laskin, A., Shutthanandan, V., Zheng, J., Zhang, R., Gaffney, J., Marley, N. A., Paredes-Miranda, G., Arnott, W. P., Molina, L. T., Sosa, G., and Jimenez, J. L.: Mexico City aerosol analysis during MILAGRO using high resolution aerosol mass spectrometry at the urban supersite (T0) - Part 1: Fine particle composition and organic source apportionment, Atmos. Chem. Phys., 9, 66336653, doi:10.5194/acp-9-6633-2009, 2009.

Alfarra, M. R.: Insights into the atmospheric organic aerosols using an aerosol mass spectrometer, Ph.D. thesis, University of Manchester, Manchester, UK, 2004.

Allan, J. D., Delia, A. E., Coe, H., Bower, K. N., Alfarra, M. R., Jimenez, J. L., Middlebrook, A. M., Drewnick, F., Onasch, T. B., Canagaratna, M. R., Jayne, J. T., and Worsnopf, D. R.: A generalised method for the extraction of chemically resolved mass spectra from aerodyne aerosol mass spectrometer data, J. Aerosol Sci., 35, 909-922, doi:10.1016/j.jaerosci.2004.02.007, 2004.

Bahreini, R., Keywood, M. D., Ng, N. L., Varutbangkul, V., Gao, S., Flagan, R. C., Seinfeld, J. H., Worsnop, D. R., and Jimenez, J. L.: Measurements of secondary organic aerosol from oxidation of cycloalkenes, terpenes, and m-xylene using an Aerodyne aerosol mass spectrometer, Environ. Sci. Technol., 39, 56745688, doi:10.1021/Es048061a, 2005.

Bateman, A. P., Nizkorodov, S. A., Laskin, J., and Laskin, A.: Time-resolved molecular characterization of limonene/ozone aerosol using high-resolution electrospray ionization mass spectrometry, Phys. Chem. Chem. Phys., 11, 7931-7942, doi:10.1039/B905288g, 2009.

Bloss, C., Wagner, V., Jenkin, M. E., Volkamer, R., Bloss, W. J., Lee, J. D., Heard, D. E., Wirtz, K., Martin-Reviejo, M., Rea, G., Wenger, J. C., and Pilling, M. J.: Development of a detailed chemical mechanism (MCMv3.1) for the atmospheric oxidation of aromatic hydrocarbons, Atmos. Chem. Phys., 5, 641-664, doi:10.5194/acp-5-641-2005, 2005.

Canagaratna, M. R., Jayne, J. T., Jimenez, J. L., Allan, J. D., Alfarra, M. R., Zhang, Q., Onasch, T. B., Drewnick, F., Coe, H., Middlebrook, A., Delia, A., Williams, L. R., Trimborn, A. M., Northway, M. J., DeCarlo, P. F., Kolb, C. E., Davidovits, P., and Worsnop, D. R.: Chemical and microphysical characterization of ambient aerosols with the aerodyne aerosol mass spectrometer, Mass Spectrom. Rev., 26, 185-222, doi:10.1002/Mas.20115, 2007.

Chan, A. W. H., Kautzman, K. E., Chhabra, P. S., Surratt, J. D., Chan, M. N., Crounse, J. D., Kurten, A., Wennberg, P. O., Flagan, R. C., and Seinfeld, J. H.: Secondary organic aerosol formation from photooxidation of naphthalene and alkylnaphthalenes: implications for oxidation of intermediate volatility organic compounds (IVOCs), Atmos. Chem. Phys., 9, 3049-3060, doi:10.5194/acp-9-3049-2009, 2009.
Chan, A. W. H., Chan, M. N., Surratt, J. D., Chhabra, P. S., Loza, C. L., Crounse, J. D., Yee, L. D., Flagan, R. C., Wennberg, P. O., and Seinfeld, J. H.: Role of aldehyde chemistry and $\mathrm{NO}_{\mathrm{x}}$ concentrations in secondary organic aerosol formation, Atmos. Chem. Phys., 10, 7169-7188, doi:10.5194/acp-10-7169-2010, 2010

Chen, Q., Liu, Y., Donahue, N. M., Shilling, J. E., and Martin, S. T.: Particle-phase chemistry of secondary organic material: Modeled compared to measured O:C and $\mathrm{H}: \mathrm{C}$ elemental ratios provide constraints, Environ. Sci. Technol., 45, 4763-4770, doi:10.1021/es104398s, 2011.

Chhabra, P. S., Flagan, R. C., and Seinfeld, J. H.: Elemental analysis of chamber organic aerosol using an aerodyne high-resolution aerosol mass spectrometer, Atmos. Chem. Phys., 10, 4111-4131, doi:10.5194/acp-10-4111-2010, 2010.

Claeys, M., Graham, B., Vas, G., Wang, W., Vermeylen, R., Pashynska, V., Cafmeyer, J., Guyon, P., Andreae, M. O., Artaxo, P., and Maenhaut, W.: Formation of secondary organic aerosols through photooxidation of isoprene, Science, 303, 1173-1176, doi:10.1126/science.1092805, 2004.

Cocker, D. R., Flagan, R. C., and Seinfeld, J. H.: State-of-theart chamber facility for studying atmospheric aerosol chemistry, Environ. Sci. Technol., 35, 2594-2601, doi:10.1021/Es0019169, 2001.

Day, D. A., Liu, S., Russell, L. M., and Ziemann, P. J.: Organonitrate group concentrations in submicron particles with high nitrate and organic fractions in coastal southern California, Atmos. Environ., 44, 1970-1979, doi:10.1016/j.atmosenv.2010.02.045, 2010.

De Gouw, J. and Jimenez, J. L.: Organic Aerosols in the Earth's Atmosphere, Environ. Sci. Technol., 43, 7614-7618, doi:10.1021/Es9006004, 2009.

DeCarlo, P. F., Kimmel, J. R., Trimborn, A., Northway, M. J., Jayne, J. T., Aiken, A. C., Gonin, M., Fuhrer, K., Horvath, T., Docherty, K. S., Worsnop, D. R., and Jimenez, J. L.: Field-deployable, high-resolution, time-of-flight aerosol mass spectrometer, Anal. Chem., 78, 8281-8289, doi:10.1021/Ac061249n, 2006.

Docherty, K. S., Wu, W., Lim, Y. B., and Ziemann, P. J.: Contributions of organic peroxides to secondary aerosol formed from reactions of monoterpenes with O-3, Environ. Sci. Technol., 39, 4049-4059, doi:10.1021/Es050228s, 2005.

Dommen, J., Metzger, A., Duplissy, J., Kalberer, M., Alfarra, M. R., Gascho, A., Weingartner, E., Prevot, A. S. H., Verheggen, B., and Baltensperger, U.: Laboratory observation of oligomers in the aerosol from isoprene/ $\mathrm{NO}_{\mathrm{x}}$ photooxidation, Geophys. Res. Lett., 33, L13805, doi:10.1029/2006g1026523, 2006.

Donahue, N. M., Robinson, A. L., and Pandis, S. N.: Atmospheric organic particulate matter: From smoke to secondary organic aerosol, Atmos. Environ., 43, 94-106, doi:10.1016/j.atmosenv.2008.09.055, 2009.

Duplissy, J., DeCarlo, P. F., Dommen, J., Alfarra, M. R., Metzger, A., Barmpadimos, I., Prevot, A. S. H., Weingartner, E., Tritscher, T., Gysel, M., Aiken, A. C., Jimenez, J. L., Canagaratna, M. R., Worsnop, D. R., Collins, D. R., Tomlinson, J., and Baltensperger, U.: Relating hygroscopicity and composition of organic aerosol particulate matter, Atmos. Chem. Phys., 11, 1155-1165, doi:10.5194/acp-11-1155-2011, 2011.

Edney, E. O., Kleindienst, T. E., Conver, T. S., McIver, C. D., Corse, E. W., and Weathers, W. S.: Polar organic oxygenates in $\mathrm{PM}_{2.5}$ at a southeastern site in the United States, Atmos. Environ., 37, 
3947-3965, doi:10.1016/S1352-2310(03)00461-8, 2003.

Farmer, D. K., Matsunaga, A., Docherty, K. S., Surratt, J. D., Seinfeld, J. H., Ziemann, P. J., and Jimenez, J. L.: Response of an aerosol mass spectrometer to organonitrates and organosulfates and implications for atmospheric chemistry, P Natl Acad Sci USA, 107, 6670-6675, doi:10.1073/pnas.0912340107, 2010.

Fisseha, R., Dommen, J., Sax, M., Paulsen, D., Kalberer, M., Maurer, R., Hofler, F., Weingartner, E., and Baltensperger, U.: Identification of organic acids in secondary organic aerosol and the corresponding gas phase from chamber experiments, Anal. Chem., 76, 6535-6540, doi:10.1021/Ac048975f, 2004.

Forstner, H. J. L., Flagan, R. C., and Seinfeld, J. H.: Secondary organic aerosol from the photooxidation of aromatic hydrocarbons: Molecular composition, Environ. Sci. Technol., 31, 1345-1358, doi:10.1021/es9605376, 1997.

Galloway, M. M., Chhabra, P. S., Chan, A. W. H., Surratt, J. D., Flagan, R. C., Seinfeld, J. H., and Keutsch, F. N.: Glyoxal uptake on ammonium sulphate seed aerosol: reaction products and reversibility of uptake under dark and irradiated conditions, Atmos. Chem. Phys., 9, 3331-3345, doi:10.5194/acp-9-3331-2009, 2009.

Gao, S., Keywood, M., Ng, N. L., Surratt, J., Varutbangkul, V., Bahreini, R., Flagan, R. C., and Seinfeld, J. H.: Low-molecularweight and oligomeric components in secondary organic aerosol from the ozonolysis of cycloalkenes and $\alpha$-pinene, J. Phys. Chem. A, 108, 10 147-10 164, doi:10.1021/jp047466e, 2004.

Goldstein, A. H. and Galbally, I. E.: Known and unexplored organic constituents in the earth's atmosphere, Environ. Sci. Technol., 41, 1514-1521, doi:10.1021/es072476p, 2007.

Gomez-Gonzalez, Y., Surratt, J. D., Cuyckens, F., Szmigielski, R., Vermeylen, R., Jaoui, M., Lewandowski, M., Offenberg, J. H., Kleindienst, T. E., Edney, E. O., Blockhuys, F., Van Alsenoy, C., Maenhaut, W., and Claeys, M.: Characterization of organosulfates from the photooxidation of isoprene and unsaturated fatty acids in ambient aerosol using liquid chromatography/(-) electrospray ionization mass spectrometry, J. Mass Spectrom., 43, 371-382, doi:10.1002/Jms.1329, 2008.

Hall, W. A. and Johnston, M. V.: Oligomer Content of $\alpha$ pinene secondary organic aerosol, Aerosol Sci. Tech., 45, 37-45, doi:10.1080/02786826.2010.517580, 2011.

Hallquist, M., Wenger, J. C., Baltensperger, U., Rudich, Y., Simpson, D., Claeys, M., Dommen, J., Donahue, N. M., George, C., Goldstein, A. H., Hamilton, J. F., Herrmann, H., Hoffmann, T., Iinuma, Y., Jang, M., Jenkin, M. E., Jimenez, J. L., KiendlerScharr, A., Maenhaut, W., McFiggans, G., Mentel, T. F., Monod, A., Prevot, A. S. H., Seinfeld, J. H., Surratt, J. D., Szmigielski, R., and Wildt, J.: The formation, properties and impact of secondary organic aerosol: current and emerging issues, Atmos. Chem. Phys., 9, 5155-5236, doi:10.5194/acp-9-5155-2009, 2009.

Hamilton, J. F., Webb, P. J., Lewis, A. C., and Reviejo, M. M.: Quantifying small molecules in secondary organic aerosol formed during the photo-oxidation of toluene with hydroxyl radicals, Atmos. Environ., 39, 7263-7275, doi:10.1016/j.atmosenv.2005.09.006, 2005.

Hawthorne, S. B., Miller, D. J., Langenfeld, J. J., and Krieger, M. S.: Pm-10 High-Volume Collection and Quantitation of Semivolatile and Nonvolatile Phenols, Methoxylated Phenols, Alkanes, and Polycyclic Aromatic-Hydrocarbons from Winter Urban Air and
Their Relationship to Wood Smoke Emissions, Environ. Sci. Technol., 26, 2251-2262, doi:10.1021/es00035a026, 1992.

Heald, C. L., Kroll, J. H., Jimenez, J. L., Docherty, K. S., DeCarlo, P. F., Aiken, A. C., Chen, Q., Martin, S. T., Farmer, D. K., and Artaxo, P.: A simplified description of the evolution of organic aerosol composition in the atmosphere, Geophys. Res. Lett., 37, L08 803, doi:10.1029/2010g1042737, 2010.

Jang, M. S. and Kamens, R. M.: Characterization of secondary aerosol from the photooxidation of toluene in the presence of $\mathrm{NO}_{\mathrm{x}}$ and 1-propene, Environ. Sci. Technol., 35, 3626-3639, doi:10.1021/Es010676+, 2001.

Jaoui, M. and Kamens, R. M.: Mass balance of gaseous and particulate products analysis from alpha-pinene/ $\mathrm{NO}_{\mathrm{X}} /$ air in the presence of natural sunlight, J. Geophys. Res.-Atmos., 106, 12541 12 558, doi:10.1029/2001JD900005, 2001.

Jayne, J. T., Leard, D. C., Zhang, X. F., Davidovits, P., Smith, K. A., Kolb, C. E., and Worsnop, D. R.: Development of an aerosol mass spectrometer for size and composition analysis of submicron particles, Aerosol Sci. Technol., 33, 49-70, doi:10.1080/027868200410840, 2000.

Jimenez, J. L., Canagaratna, M. R., Donahue, N. M., Prevot, A. S. H., Zhang, Q., Kroll, J. H., DeCarlo, P. F., Allan, J. D., Coe, H., Ng, N. L., Aiken, A. C., Docherty, K. S., Ulbrich, I. M., Grieshop, A. P., Robinson, A. L., Duplissy, J., Smith, J. D., Wilson, K. R., Lanz, V. A., Hueglin, C., Sun, Y. L., Tian, J., Laaksonen, A., Raatikainen, T., Rautiainen, J., Vaattovaara, P., Ehn, M., Kulmala, M., Tomlinson, J. M., Collins, D. R., Cubison, M. J., E., Dunlea, J., Huffman, J. A., Onasch, T. B., Alfarra, M. R., Williams, P. I., Bower, K., Kondo, Y., Schneider, J., Drewnick, F., Borrmann, S., Weimer, S., Demerjian, K., Salcedo, D., Cottrell, L., Griffin, R., Takami, A., Miyoshi, T., Hatakeyama, S., Shimono, A., Sun, J. Y., Zhang, Y. M., Dzepina, K., Kimmel, J. R., Sueper, D., Jayne, J. T., Herndon, S. C., Trimborn, A. M., Williams, L. R., Wood, E. C., Middlebrook, A. M., Kolb, C. E., Baltensperger, U., and Worsnop, D. R.: Evolution of Organic Aerosols in the Atmosphere, Science, 326, 1525-1529, doi:10.1126/science.1180353, 2009.

Kautzman, K. E., Surratt, J. D., Chan, M. N., Chan, A. W. H., Hersey, S. P., Chhabra, P. S., Dalleska, N. F., Wennberg, P. O., Flagan, R. C., and Seinfeld, J. H.: Chemical Composition of Gas- and Aerosol-Phase Products from the Photooxidation of Naphthalene, J. Phys. Chem. A, 114, 913-934, doi:10.1021/jp908530s, 2009.

Kessler, S. H., Smith, J. D., Che, D. L., Worsnop, D. R., Wilson, K. R., and Kroll, J. H.: Chemical sinks of organic aerosol: kinetics and products of the heterogeneous oxidation of erythritol and levoglucosan, Environ. Sci. Technol., 44, 7005-7010, doi:10.1021/es101465m, 2010.

Keywood, M. D., Kroll, J. H., Varutbangkul, V., Bahreini, R., Flagan, R. C., and Seinfeld, J. H.: Secondary organic aerosol formation from cyclohexene ozonolysis: Effect of $\mathrm{OH}$ scavenger and the role of radical chemistry, Environ. Sci. Technol., 38, 33433350, doi:10.1021/Es049725j, 2004.

Kleindienst, T. E., Conver, T. S., McIver, C. D., and Edney, E. O.: Determination of secondary organic aerosol products from the photooxidation of toluene and their implication in ambient $\mathrm{PM}_{2.5}$, J. Atmos. Chem., 47, 79-100, doi:10.1023/B:JOCH.0000012305.94498.28, 2004.

Kroll, J. H. and Seinfeld, J. H.: Chemistry of secondary or- 
ganic aerosol: Formation and evolution of low-volatility organics in the atmosphere, Atmos. Environ., 42, 3593-3624, doi:10.1016/j.atmosenv.2008.01.003, 2008.

Kroll, J. H., Ng, N. L., Murphy, S. M., Flagan, R. C., and Seinfeld, J. H.: Secondary organic aerosol formation from isoprene photooxidation, Environ. Sci. Technol., 40, 1869-1877, doi:10.1021/Es0524301, 2006.

Kroll, J. H., Donahue, N. M., Jimenez, J. L., Kessler, S. H., Canagaratna, M. R., Wilson, K. R., Altieri, K. E., Mazzoleni, L. R., Wozniak, A. S., Bluhm, H., Mysak, E. R., Smith, J. D., Kolb, C. E., and Worsnop, D. R.: Carbon oxidation state as a metric for describing the chemistry of atmospheric organic aerosol, Nat. Chem., 3, 133-139, doi:10.1038/Nchem.948, 2011.

Kua, J., Hanley, S. W., and De Haan, D. O.: Thermodynamics and kinetics of glyoxal dimer formation: A computational study, J. Phys. Chem. A, 112, 66-72, doi:10.1021/Jp076573g, 2008.

Lambe, A. T., Onasch, T. B., Massoli, P., Croasdale, D. R., Wright, J. P., Ahern, A. T., Williams, L. R., Worsnop, D. R., Brune, W. H., and Davidovits, P.: Laboratory studies of the chemical composition and cloud condensation nuclei $(\mathrm{CCN})$ activity of secondary organic aerosol (SOA) and oxidized primary organic aerosol (OPOA), Atmos. Chem. Phys. Discuss., 11, 1361713653, doi:10.5194/acpd-11-13617-2011, 2011.

Lanz, V. A., Alfarra, M. R., Baltensperger, U., Buchmann, B., Hueglin, C., and Prevot, A. S. H.: Source apportionment of submicron organic aerosols at an urban site by factor analytical modelling of aerosol mass spectra, Atmos. Chem. Phys., 7, 15031522, doi:10.5194/acp-7-1503-2007, 2007.

Lee, A. K. Y., Herckes, P., Leaitch, W. R., Macdonald, A. M., and Abbatt, J. P. D.: Aqueous $\mathrm{OH}$ oxidation of ambient organic aerosol and cloud water organics: formation of highly oxidized products, Geophys. Res. Lett., 38, L11805, doi:10.1029/2011GL047439, 2011.

Lim, Y. B., Tan, Y., Perri, M. J., Seitzinger, S. P., and Turpin, B. J.: Aqueous chemistry and its role in secondary organic aerosol (SOA) formation, Atmos. Chem. Phys., 10, 1052110539, doi:10.5194/acp-10-10521-2010, 2010.

Loeffler, K. W., Koehler, C. A., Paul, N. M., and De Haan, D. O.: Oligomer formation in evaporating aqueous glyoxal and methyl glyoxal solutions, Environ. Sci. Technol., 40, 6318-6323, doi:10.1021/Es060810w, 2006.

Müller, L., Reinnig, M.-C., Warnke, J., and Hoffmann, T.: Unambiguous identification of esters as oligomers in secondary organic aerosol formed from cyclohexene and cyclohexene $/ \alpha-$ pinene ozonolysis, Atmos. Chem. Phys., 8, 1423-1433, doi:10.5194/acp-8-1423-2008, 2008.

Ng, N. L., Kroll, J. H., Chan, A. W. H., Chhabra, P. S., Flagan, R. C., and Seinfeld, J. H.: Secondary organic aerosol formation from m-xylene, toluene, and benzene, Atmos. Chem. Phys., 7, 3909-3922, doi:10.5194/acp-7-3909-2007, 2007.

Ng, N. L., Canagaratna, M. R., Zhang, Q., Jimenez, J. L., Tian, J., Ulbrich, I. M., Kroll, J. H., Docherty, K. S., Chhabra, P. S., Bahreini, R., Murphy, S. M., Seinfeld, J. H., Hildebrandt, L., Donahue, N. M., DeCarlo, P. F., Lanz, V. A., Prevot, A. S. H., Dinar, E., Rudich, Y., and Worsnop, D. R.: Organic aerosol components observed in Northern Hemispheric datasets from Aerosol Mass Spectrometry, Atmos. Chem. Phys., 10, 46254641, doi:10.5194/acp-10-4625-2010, 2010.

Ng, N. L., Canagaratna, M. R., Jimenez, J. L., Chhabra, P. S., Se- infeld, J. H., and Worsnop, D. R.: Changes in organic aerosol composition with aging inferred from aerosol mass spectra, Atmos. Chem. Phys., 11, 6465-6474, doi:10.5194/acp-11-64652011, 2011.

Reinhardt, A., Emmenegger, C., Gerrits, B., Panse, C., Dommen, J., Baltensperger, U., Zenobi, R., and Kalberer, M.: Ultrahigh mass resolution and accurate mass measurements as a tool to characterize oligomers in secondary organic aerosols, Anal. Chem., 79, 4074-4082, doi:10.1021/Ac062425v, 2007.

Robinson, A. L., Donahue, N. M., Shrivastava, M. K., Weitkamp, E. A., Sage, A. M., Grieshop, A. P., Lane, T. E., Pierce, J. R., and Pandis, S. N.: Rethinking organic aerosols: Semivolatile emissions and photochemical aging, Science, 315, 1259-1262, doi:10.1126/science.1133061, 2007.

Rollins, A. W., Fry, J. L., Hunter, J. F., Kroll, J. H., Worsnop, D. R., Singaram, S. W., and Cohen, R. C.: Elemental analysis of aerosol organic nitrates with electron ionization highresolution mass spectrometry, Atmos. Meas. Tech., 3, 301-310, doi:10.5194/amt-3-301-2010, 2010.

Rudich, Y., Donahue, N. M., and Mentel, T. F.: Aging of organic aerosol: bridging the gap between laboratory and field studies, Annu. Rev. Phys. Chem., 58, 321-352, doi:10.1146/annurev.physchem.58.032806.104432, 2007.

Russell, L. M.: Aerosol organic-mass-to-organic-carbon ratio measurements, Environ. Sci. Technol., 37, 2982-2987, doi:10.1021/Es026123w, 2003.

Russell, L. M., Takahama, S., Liu, S., Hawkins, L. N., Covert, D. S., Quinn, P. K., and Bates, T. S.: Oxygenated fraction and mass of organic aerosol from direct emission and atmospheric processing measured on the $R / V$ Ronald Brown during TEXAQS/GoMACCS 2006, J. Geophys. Res.-Atmos., 114, D00F05, doi:10.1029/2008jd011275, 2009.

Sato, K., Hatakeyama, S., and Imamura, T.: Secondary organic aerosol formation during the photooxidation of toluene: $\mathrm{NO}_{\mathrm{x}}$ dependence of chemical composition, J. Phys. Chem. A, 111, 9796-9808, doi:10.1021/Jp071419f, 2007.

Shilling, J. E., Chen, Q., King, S. M., Rosenoern, T., Kroll, J. H., Worsnop, D. R., DeCarlo, P. F., Aiken, A. C., Sueper, D., Jimenez, J. L., and Martin, S. T.: Loading-dependent elemental composition of alpha-pinene SOA particles, Atmos. Chem. Phys., 9, 771-782, doi:10.5194/acp-9-771-2009, 2009.

Sun, Y. L., Zhang, Q., Anastasio, C., and Sun, J.: Insights into secondary organic aerosol formed via aqueous-phase reactions of phenolic compounds based on high resolution mass spectrometry, Atmos. Chem. Phys., 10, 4809-4822, doi:10.5194/acp-104809-2010, 2010.

Surratt, J. D., Murphy, S. M., Kroll, J. H., Ng, N. L., Hildebrandt, L., Sorooshian, A., Szmigielski, R., Vermeylen, R., Maenhaut, W., Claeys, M., Flagan, R. C., and Seinfeld, J. H.: Chemical composition of secondary organic aerosol formed from the photooxidation of isoprene, J. Phys. Chem. A, 110, 9665-9690, doi:10.1021/Jp061734m, 2006.

Surratt, J. D., Lewandowski, M., Offenberg, J. H., Jaoui, M., Kleindienst, T. E., Edney, E. O., and Seinfeld, J. H.: Effect of acidity on secondary organic aerosol formation from isoprene, Environ. Sci. Technol., 41, 5363-5369, doi:10.1021/Es0704176, 2007.

Surratt, J. D., Chan, A. W. H., Eddingsaas, N. C., Chan, M. N., Loza, C. L., Kwan, A. J., Hersey, S. P., Flagan, R. C., Wennberg, P. O., and Seinfeld, J. H.: Reactive in- 
termediates revealed in secondary organic aerosol formation from isoprene, P. Natl. Acad. Sci. USA, 107, 6640-6645, doi:10.1073/pnas.0911114107, 2010.

Szmigielski, R., Surratt, J. D., Vermeylen, R., Szmigielska, K., Kroll, J. H., Ng, N. L., Murphy, S. M., Sorooshian, A., Seinfeld, J. H., and Claeys, M.: Characterization of 2-methylglyceric acid oligomers in secondary organic aerosol formed from the photooxidation of isoprene using trimethylsilylation and gas chromatography/ion trap mass spectrometry, J. Mass Spectrom., 42, 101-116, doi:10.1002/Jms.1146, 2007.

Takegawa, N., Miyakawa, T., Kawamura, K., and Kondo, Y.: Contribution of selected dicarboxylic and omega-oxocarboxylic acids in ambient aerosol to the $\mathrm{m} / \mathrm{z} 44$ signal of an aerodyne aerosol mass spectrometer, Aerosol Sci. Technol., 41, 418-437, doi:10.1080/02786820701203215, 2007.

Tolocka, M. P., Heaton, K. J., Dreyfus, M. A., Wang, S. Y., Zordan, C. A., Saul, T. D., and Johnston, M. V.: Chemistry of particle inception and growth during alpha-pinene ozonolysis, Environ. Sci. Technol., 40, 1843-1848, doi:10.1021/Es051926f, 2006.

Ulbrich, I. M., Canagaratna, M. R., Zhang, Q., Worsnop, D. R., and Jimenez, J. L.: Interpretation of organic components from Positive Matrix Factorization of aerosol mass spectrometric data, Atmos. Chem. Phys., 9, 2891-2918, doi:10.5194/acp-9-2891-2009, 2009.

Walser, M. L., Desyaterik, Y., Laskin, J., Laskin, A., and Nizkorodov, S. A.: High-resolution mass spectrometric analysis of secondary organic aerosol produced by ozonation of limonene, Phys. Chem. Chem. Phys., 10, 1009-1022, doi:10.1039/B712620d, 2008.
Wang, W., Kourtchev, I., Graham, B., Cafmeyer, J., Maenhaut, W., and Claeys, M.: Characterization of oxygenated derivatives of isoprene related to 2-methyltetrols in Amazonian aerosols using trimethylsilylation and gas chromatography/ion trap mass spectrometry, Rapid Commun. Mass Spectrom., 19, 1343-1351, doi:10.1002/Rcm.1940, 2005.

Yu, J. Z., Cocker, D. R., Griffin, R. J., Flagan, R. C., and Seinfeld, J. H.: Gas-phase ozone oxidation of monoterpenes: Gaseous and particulate products, J. Atmos. Chem., 34, 207-258, doi:10.1023/A:1006254930583, 1999.

Zhang, Q., Alfarra, M. R., Worsnop, D. R., Allan, J. D., Coe, H., Canagaratna, M. R., and Jimenez, J. L.: Deconvolution and quantification of hydrocarbon-like and oxygenated organic aerosols based on aerosol mass spectrometry, Environ. Sci. Technol., 39, 4938-4952, doi:10.1021/Es0485681, 2005.

Zhang, Q., Jimenez, J. L., Canagaratna, M. R., Allan, J. D., Coe, H., Ulbrich, I., Alfarra, M. R., Takami, A., Middlebrook, A. M., Sun, Y. L., Dzepina, K., Dunlea, E., Docherty, K., DeCarlo, P. F., Salcedo, D., Onasch, T., Jayne, J. T., Miyoshi, T., Shimono, A., Hatakeyama, S., Takegawa, N., Kondo, Y., Schneider, J., Drewnick, F., Borrmann, S., Weimer, S., Demerjian, K., Williams, P., Bower, K., Bahreini, R., Cottrell, L., Griffin, R. J., Rautiainen, J., Sun, J. Y., Zhang, Y. M., and Worsnop, D. R.: Ubiquity and dominance of oxygenated species in organic aerosols in anthropogenically-influenced Northern Hemisphere midlatitudes, Geophys. Res. Lett., 34, L13801, doi:10.1029/2007g1029979, 2007. 